SUSPENDED-SEDIMENT YIELDS IN THE COAL RIVER

AND TRACE FORK BASINS, WEST VIRGINIA, 1975-84

By Stephen M. Ward and D. H. Appe1

U.S. GEOLOGICAL SURVEY

Water-Resources Investigations Report 87-4171

Prepared in cooperation with the

WEST VIRGINIA DEPARTMENT OF HIGHWAYS

WEST VIRGINIA DEPARTMENT OF NATURAL RESOURCES

Charleston, West Virginia

1988 
DEPARTMENT OF THE INTERIOR

DONALD PAUL HODEL, Secretary

U.S. GEOLOGICAL SURVEY

Dallas L. Peck, Director

For additional information write to:

District Chief

U.S. Geological Survey, WRD 603 Morris Street

Charleston, WV 25301
Copies of the report can be purchased from:

Open-File Services Section Western Distribution Branch U.S. Geological Survey Box 25425, Federal Center Denver, CO 80225 
CONTENTS

Page

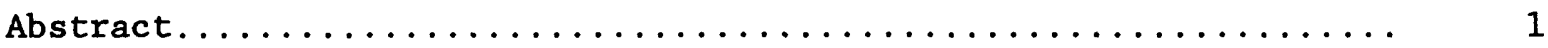

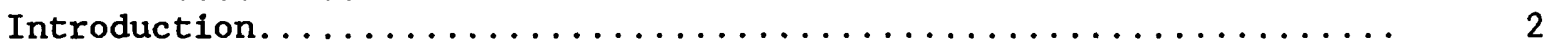

Basin characteristics affecting sediment yields.............. 5

Surface drainage.............................. 5

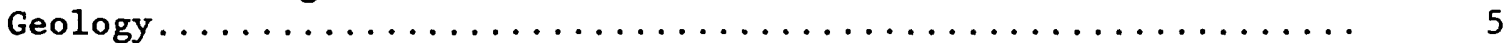

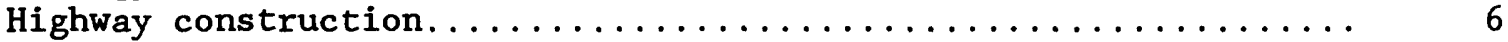

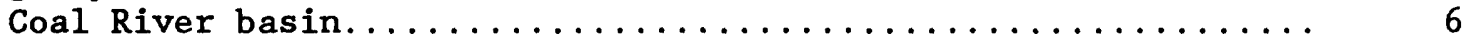

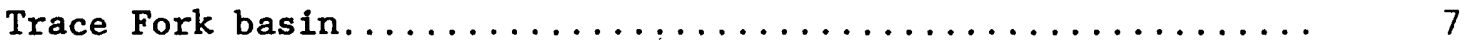

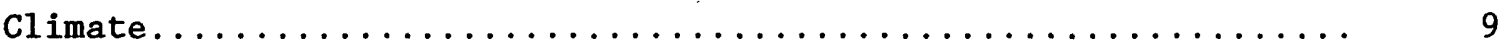

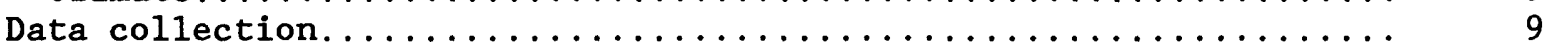

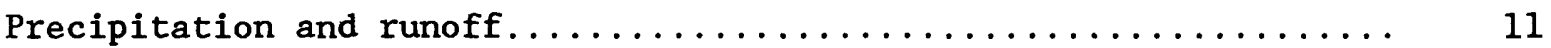

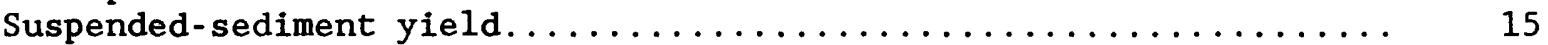

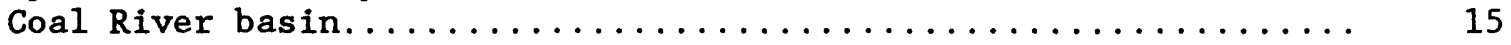

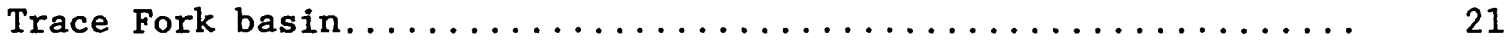

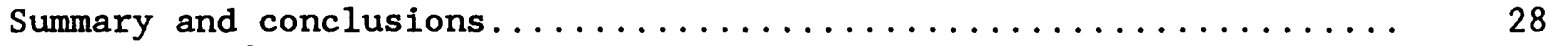

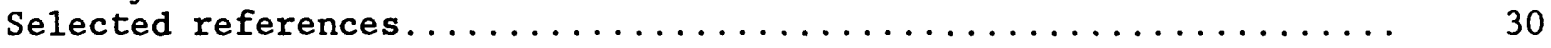

Appendix--Daily Precipitation Data................... 33 


\section{ILLUSTRATIONS}

Page

Figure 1. Map showing Coal River and Trace Fork study area....... 3

2. Graph showing stream profile of Coal River from above

Danville to mouth, with mainstem sampling sites...... 6

3. Map showing Trace Fork basin and Appalachian

Corridor $\mathrm{G}$ highway....................... 8

4-12. Graphs showing:

4. Annual precipitation at Dry Creek, Madison, Charleston, and Ruth.................. 12

5. Departure from normal annual precipitation at Madison, water years 1975-84.

6. Curves of relation between daily suspendedsediment discharge and streamflow at sites in the Coal River basin, water years 1975-84..... 18

7. Relation of cumulative annual suspended-sediment yield and time at sites in the Coal River

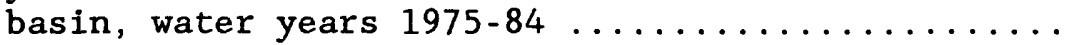

8. Relation of cumulative annual suspended-sediment yield and cumulative runoff at sites in the Coal River basin, water years $1975-84 \ldots \ldots \ldots \ldots 20$

9. Monthly suspended-sediment load at Trace Fork downstream from Dryden Hollow at Ruth, July 1980 through September 1984

10. Cumulative monthly suspended-sediment yield for Trace Fork at Ruth and Trace Fork downstream from Dryden Hollow at Ruth, July 1980 through September 1984.........

11. Cumulative monthly suspended sediment and streamflow from Trace Fork downstream from Dryden Hollow at Ruth, July 1980 through September 1984 , site $2 \ldots \ldots \ldots \ldots \ldots \ldots$

12. Curves of relation between daily suspendedsediment discharge and streamflow at sites in the Trace Fork basin, July 1980 through September 1984 
TABLES

Page

Table 1. Data-collection sites in study area.............. 4

2. Monthly and annual precipitation at Madison, water

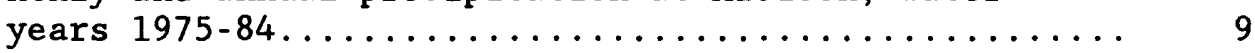

3. Annual precipitation at Madison, and annual runoff at gaging sites in the Coal River basin, water

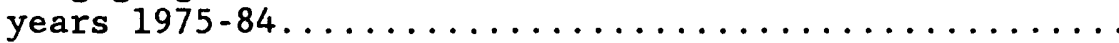

4. Annual precipitation at Dryden Hollow, and annual runoff at gaging sites in the Trace Fork basin, water years $1980-84$, in inches................ 15

5. Annual suspended-sediment load and yield at selected mainstem sites in the Coal River basin........... 16

6. Annual suspended-sediment load and yield for Trace

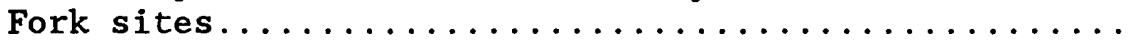

\section{CONVERSION FACTORS AND ABBREVIATIONS}

The following factors may be used to convert the inch-pound units published herein to the metric (International System) units.

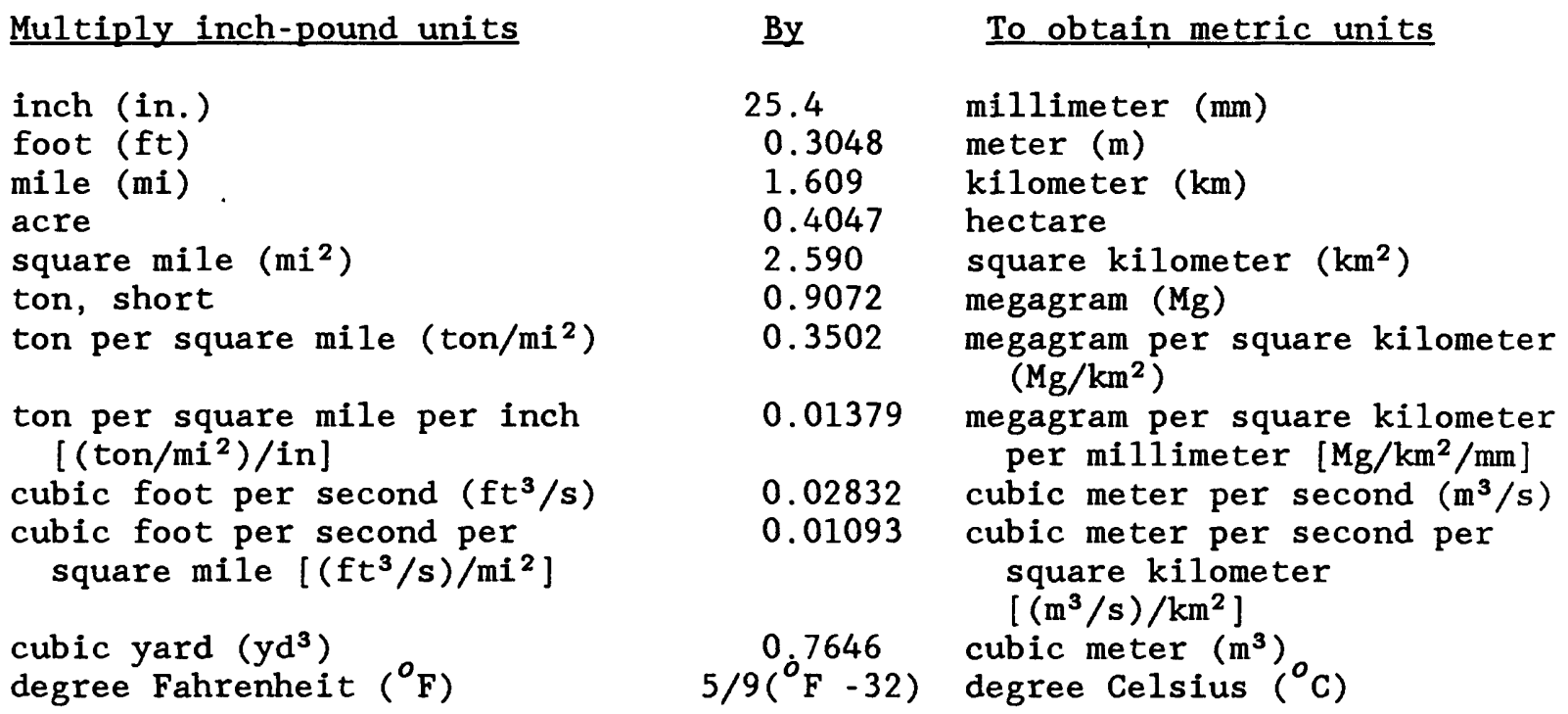

Sea Level. In this report "sea level" refers to the National Geodetic Vertical Datum of 1929 (NGVD of 1929)--a geodetic datum derived from a general adjustment of the first-order level nets of both the United States and Canada, formerly called "Mean Sea Level of 1929." 


\title{
SUSPENDED-SEDIMENT YIELDS IN THE COAL RIVER AND \\ TRACE FORK BASINS, WEST VIRGINIA, 1975-84
}

By Stephen M. Ward and D. H. Appel

\begin{abstract}
Suspended-sediment yields associated with highway construction of the four-lane Appalachian Corridor $G$ were studied in the Coal River and Trace Fork basins in southern West Virginia. Streamflow and sediment data were collected in the Coal River basin and in basins of its major tributaries, the Little Coal and Big Coal Rivers, from 1973 to 1984. Precipitation, streamflow, and sediment data were collected in the smaller Trace Fork basin (4.72 square miles) from July 1980 through September 1984 to evaluate the effects of highway construction in a smaller drainage basin with limited additional land uses.

The effect of highway construction on runoff and suspendedsediment yield in the Coal River and its major tributaries was difficult to detect. Drainage areas of the mainstem sites in the Coal River basin ranged from 269 to 862 square miles, and average annual suspended-sediment yields ranged from 113 to 1,000 tons per square mile for the period 1975-84. Suspended-sediment load in the smaller Trace Fork basin was significantly affected by a 0.29 -square mile area of highway construction. Based on data from undisturbed areas upstream from construction, the normal load at Trace Fork downstream from construction during July 1980 through September 1984 was estimated to be 3,520 tons; the measured load was 6,970 tons. Runoff from the area disturbed by highway construction transported approximately 3,450 tons of sediment during that same period.
\end{abstract}




\section{INTRODUCTION}

The U.S. Geological Survey, in cooperation with the West Virginia Department of Highways and Department of Natural Resources, has collected streamflow and sediment data in the Coal River basin from 1973 to 1984 and in the Trace Fork basin from 1980 to 1984. The data were collected to determine the sediment yields associated with highway construction. The study areas are affected by construction of Appalachian Corridor G--a divided four-lane highway connecting southern West Virginia with the Interstate Highway System at Charleston--and by other land uses, such as coal mining and logging. Disturbance of land has the potential to increase the sediment load in streams draining the affected areas.

After highway construction in the basin started in 1972, streamflow and suspended-sediment data were collected at selected sites upstream and downstream from highway construction in the Coal River and Trace Fork basins to determine the amount of suspended sediment transported between the sites. The data-collection sites are shown in figure 1. Information for the sites, including type of data, period of record, and land use are given in table 1. Streamflow and sediment data for the Coal River at Alum Creek (site 6) were not used in this report analysis, inasmuch as the drainage areas between sites 6 and 7 differ by only 2.5 percent.

An interim report, "Progress Report on the Effects of Highway Construction on Suspended-Sediment Discharge in the Coal River and Trace Fork, West Virginia, 1975-81" (Downs and Appe1, 1986), describes the preliminary results of the study to determine the effects of highway construction on suspended-sediment discharges in the Coal River and Trace Fork basins resulting from construction of Appalachian Corridor $G$ for the period October 1974 through September 1981 (water years 1975-81) ${ }^{1}$.

This report includes an additional 3 years of data that were collected from October 1981 to September 1984. These data support the findings of the interim report. This report describes the results of the study to determine the effects of highway construction on suspended-sediment discharges in the Coal River and Trace Fork basins resulting from construction of Appalachian Corridor $G$ for the period October 1974 through September 1984 (water years 1975-84).

1 All "annual or yearly" references in this report are for water years. A water year is defined as the 12 -month period beginning October 1 and ending September 30; it is designated by the calendar year in which it ends. 


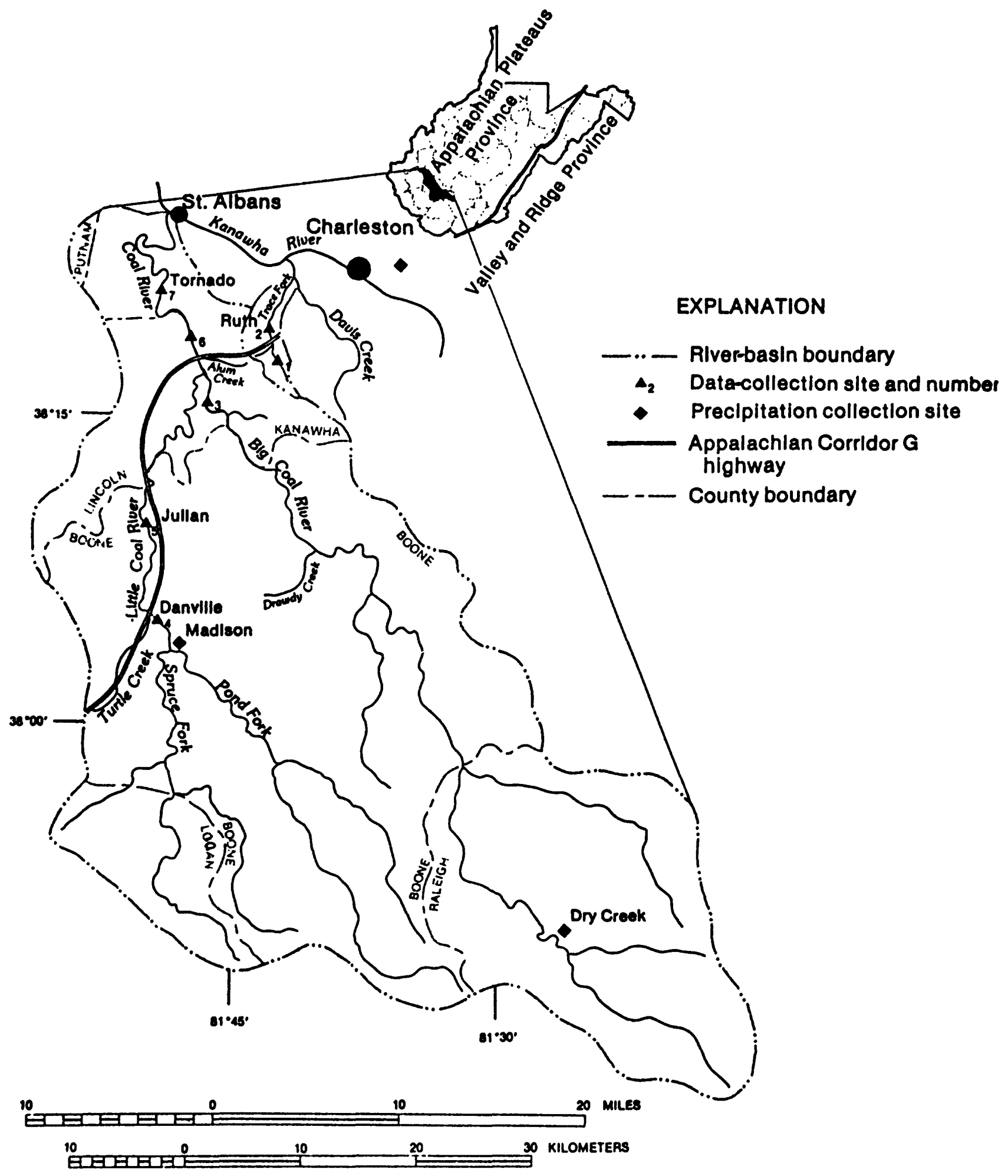

Figure 1. Coal River and Trace Fork study area. 


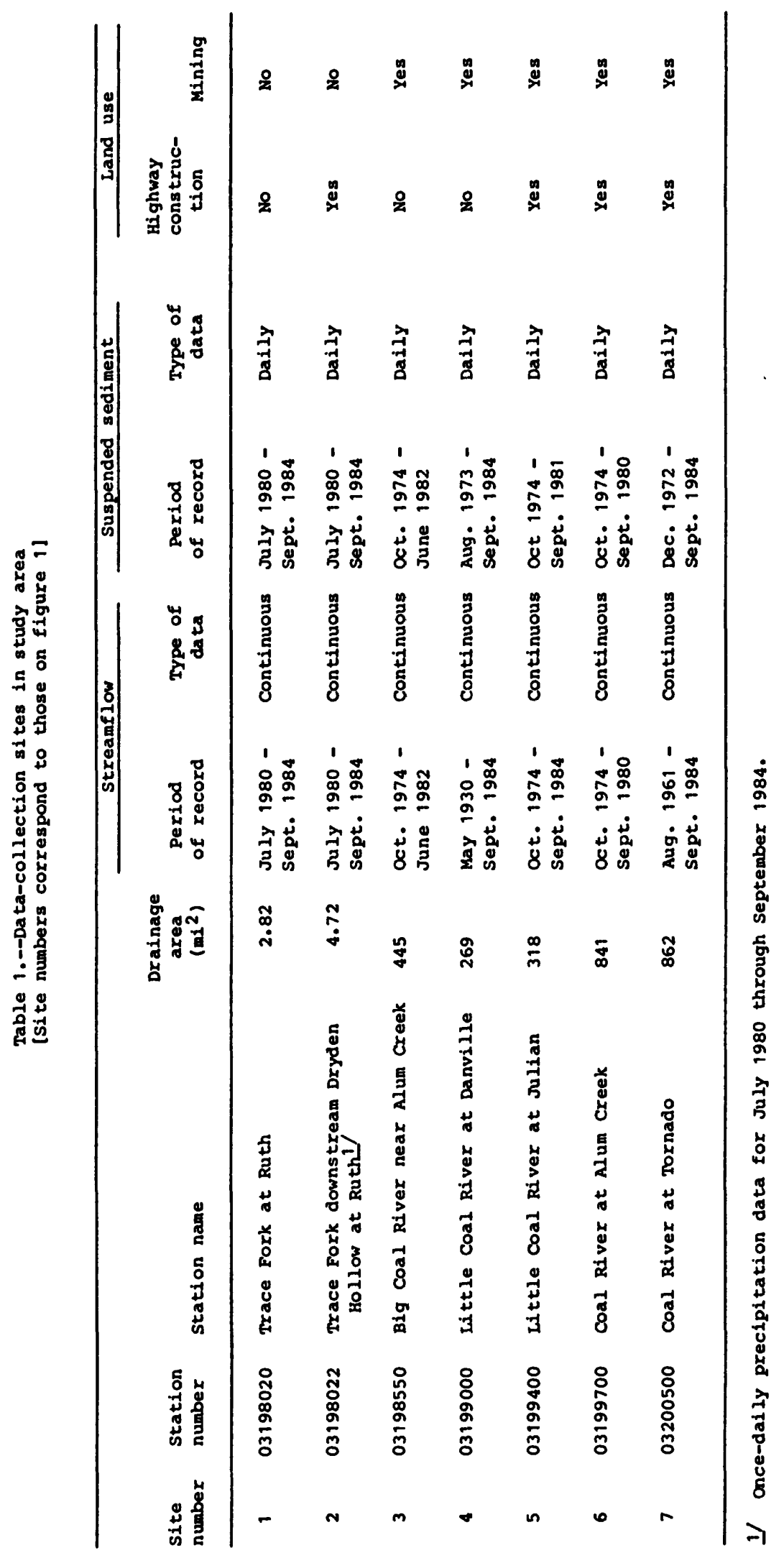




\section{BASIN CHARACTERISTICS AFFECTING SEDIMENT YIELDS}

\section{Surface Drainage}

The Coal River basin drains $890 \mathrm{mi}^{2}$ (square miles) in the Appalachian Plateaus physiographic province in southern West Virginia (Fenneman and Johnson, 1946). Coal River, which is a tributary to the Kanawha River (fig.1), has two main tributaries--the Big Coal River and the Little Coal River. The Coal River and its two main tributaries are referred to as the Coal River mainstem in this report. The basin is an area of densely forested mountains ranging in elevation from $570 \mathrm{ft}$ (feet) above sea leve 1 at the mouth at St. Albans to more than 3,600 ft above sea level at the southern boundary of the basin near the Boone-Raleigh County line. A stream profile showing the elevation and distance from the mouth of all the Coal River mainstem sites is shown in figure 2. Valley walls are moderately steep to very steep.

The steep slopes and rough topography are subject to severe soil erosion. The basin includes parts of six counties--Boone, Kanawha, Lincoln, Logan, Putnam, and Raleigh--with Boone constituting more than half the total area.

The Trace Fork basin adjoins the Coal River basin (fig. 1), but is a tributary to Davis Creek, which flows into the Kanawha River. Trace Fork below Dryden Hollow at Ruth (site 2)--the basin outflow site--has a drainage area of $4.72 \mathrm{mi}^{2}$. The basin elevation ranges from $650 \mathrm{ft}$ above sea level at site 2 to about $1,250 \mathrm{ft}$ above sea level at the southern boundary of the basin. Dryden Hollow, a major tributary to Trace Fork upstream from site 2 (fig. 3), has a channel slope of $218 \mathrm{ft} / \mathrm{mi}$ (feet per mile) between the basin divide and its confluence with Trace Fork. The stream bed at site 1 (Trace Fork near Ruth) consists primarily of cobble and rock, whereas at site 2, the stream bed is a bedrock shelf.

\section{$\underline{\text { Geology }}$}

The consolidated sedimentary rocks of Pennsylvanian age that underlie the Coal River and Trace Fork basins are divided into five stratigraphic units. They are, from the oldest to the youngest: The New River Formation and Kanawha Formation of the Pottsville Group, the Allegheny Formation, the Conemaugh Group, and the Monongahela Group (Cardwe 11 and others, 1968). The stratigraphic nomenclature used in this report follows the usage of the West Virginia Geological and Economic Survey and does not necessarily conform to that used by the U.S. Geological Survey. The consolidated rocks consist chiefly of sandstone, shale, siltstone, coal, and underclay. Soils on hilltops and hillsides are classified as deep to moderately deep, we11-drained channery loams and channery sandy loams (Van Houten and others, 1981). Because of the steep land slopes, the soils in the study area are considered to be very erodible.

Shallow deposits of alluvium, typically less than $10 \mathrm{ft}$ thick, are present on the valley floors of the Coal, Big Coal, and Little Coal Rivers and Trace Fork. Most of these deposits consist of poorly sorted gravel, sand, silt, and clay. The only significant alluvial deposit in the study area is near the mouth of the Coal River at St. Albans, W. Va. 


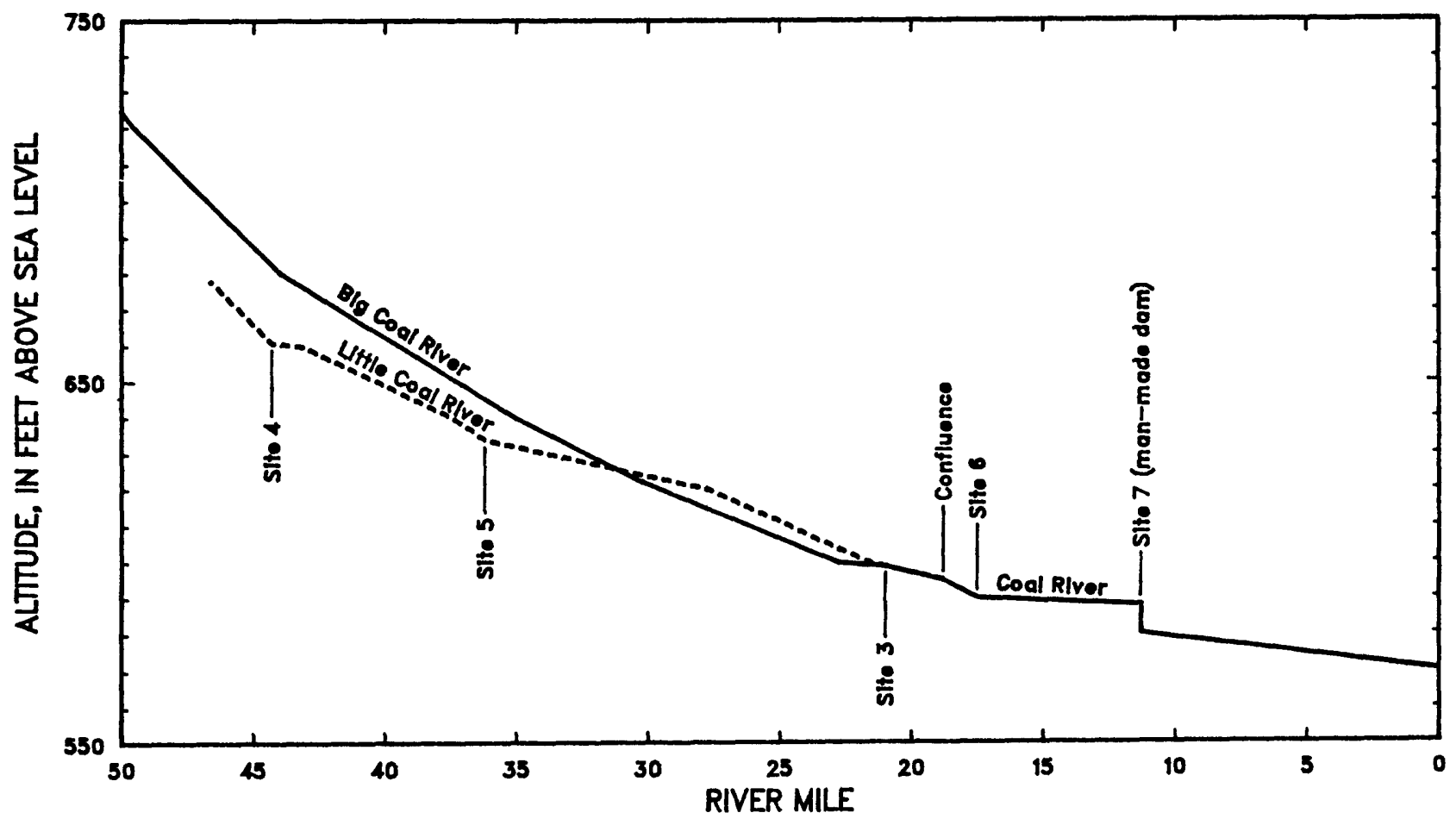

Figure 2. Stream profile of Coal River from above Danville to mouth, with mainstem sampling sites.

\section{Highway Construction}

Coal River Basin

Major land disturbances in the Little Coal River basin during 1975-84 were surface and deep coal-mine operations, logging, and highway construction on Appalachian Corridor G. Land use in Boone County, which is typical of the basin, is 93 percent forest, 3 percent surface mines and quarries, 2 percent residential and industrial, and 2 percent miscellaneous (McColloch and Lessing, 1980).

From 1972 through 1975, Appalachian Corridor G construction occurred along Turtle Creek (fig. 1)--a tributary to the Little Coal River downstream from Danville; no highway construction occurred in the Little Coal River basin upstream from Danville. During construction of the Turtle Creek segment, most of the vegetation was removed and approximately 3.5 million $\mathrm{yd}^{3}$ (cubic yards) of material was excavated. Almost 60 percent of the stream channel was relocated to accommodate the new highway (Chisholm and Downs, 1978). Bader and others (in press) estimated that Turtle Creek subbasin total suspended load was 34,000 tons during 1973 and 1974 [a yield of 1,400 (tons $/ \mathrm{mi}^{2}$ ) yr (tons per square mile per year)]. Virtually no logging or surface mining activity occurred in the basin during this period. Eckhardt (1976) reported that suspended-sediment yields from highway construction can be as high as 66,000 (tons $/ \mathrm{mi}^{2}$ ) $/ \mathrm{yr}$. 
From 1975 through 1984, no major highway construction occurred in the drainage basin between the Little Coal River gaging stations at Danville and Julian (sites 4 and 5). From January 1979 through September 1981, about 700 acres of right-of-way were cleared (approximately 0.1 percent of the basin area), and approximately 18 million $\mathrm{yd}^{3}$ of material was excavated along a 12 -mile segment of new highway between Julian and the confluence of the Little and Big Coal Rivers. From the confluence of the Little and Big Coal Rivers, construction continued in an easterly direction towards Charleston, passing through the Trace Fork study area.

\section{Trace Fork Basin}

The only major land disturbance in the Trace Fork basin during the study period was the construction of Appalachian Corridor G highway. The highway crosses Trace tork approximately $\frac{1}{4}$ mile downstream from Ruth and parallels the full length of Dryden Hollow--a major tributary to Trace Fork (fig. 3). No mining, logging, or other major sedimentary-producing activities occurred in the Trace Fork basin upstream from the confiuence of Dryden Hollow during the study period. This area is relatively undisturbed, except for some single-family houses and unimproved roads. Nearly 4.8 million $\mathrm{yd}^{3}$ of material was excavated for the 2 miles of highway which bisected the basin.

From July 1979 through May 1980, about 128 acres of right-ofway area were clesred of vegetation (approximately 4.2 percent of the basin area), and, from October 1979 through July 1981, approximately 3 million $\mathrm{yd}^{3}$ of material was excavated in the 1.5 -mile serment (first phase) of new highway in the basin. Paving of this section of highway ended in late November 1981. Final cleanup and reseeding for this phase of construction, which ended in May 1982, completed the first phase of highway construction in the basin. Virtually no soil-disturbing activities related to highway construction occurred again until May 1984. This 25-month period (May 1982 through May 1984) allowed vegetation to cover and stabilize the exposed soils associated with the highway construction. In late May 1984, clearing started for the second phase of the highway construction. An additional 59 acres of right-of-way were cleared of vegetation, making a total of 187 acres (approximately 6.2 percent of the basin area) for both phases of construction in the study area. Excavations for the final 0.5 mile segment started in June 1984, just 4 months prior to the end of the data-collection program. Nearly 1.8 million $\mathrm{yd}^{3}$ of material was excavated along this final segment of highway. Excavations for this second segment ended in November 1984, and paving was completed in June 1986. 


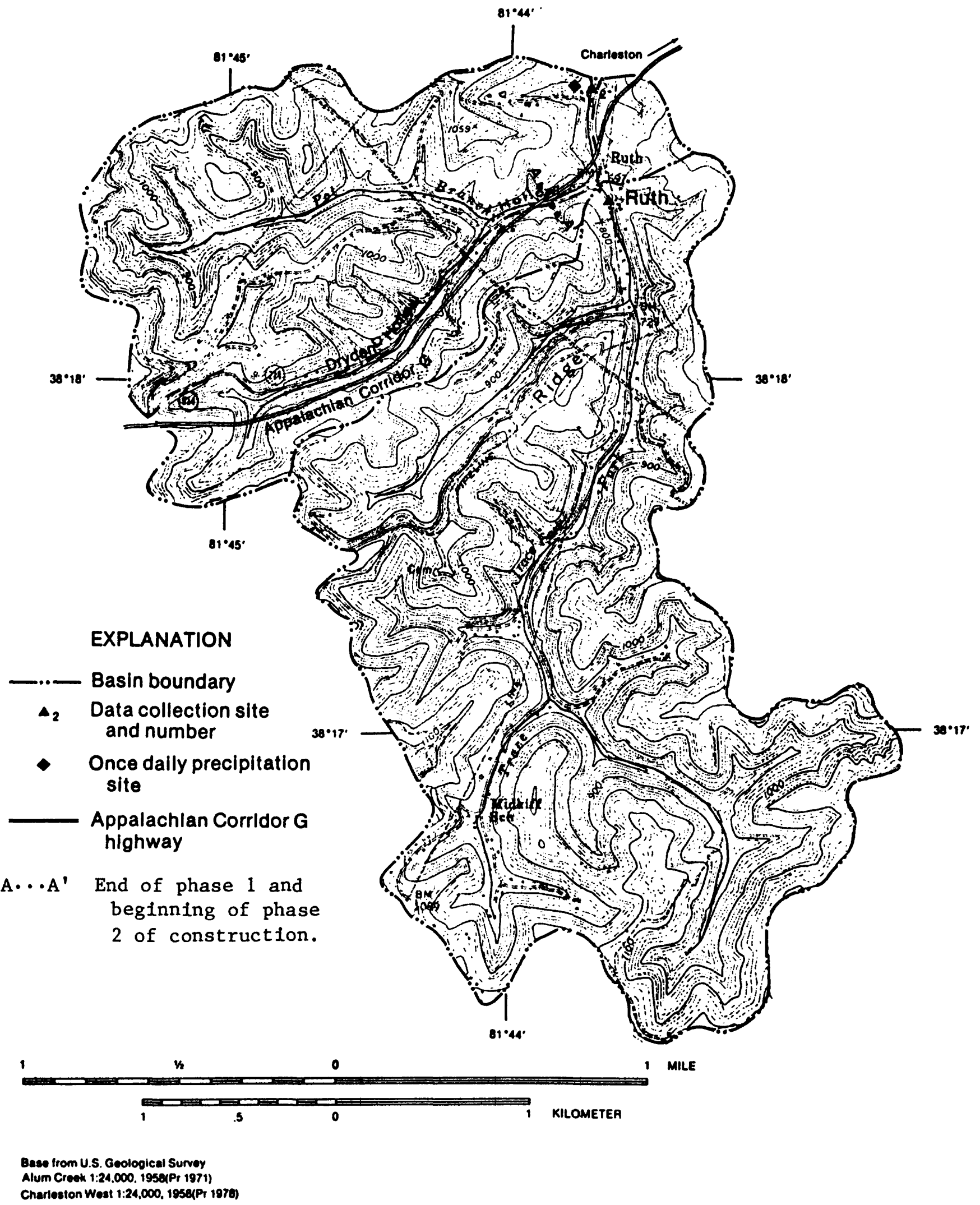

Figure 3. Trace Fork basin and Appalachian Corridor G highway. 


\section{Climate}

Climate in the Coal River basin is continental inland, which is characterized by warm, humid summers and long winters. The prevailing winds are from the west and northwest (U.S. Department of Commerce, 1977). Average daily temperatures in January and July are about $34^{\circ} \mathrm{F}$ and $75^{\circ} \mathrm{F}$, respectively. The average length of the frost-free season is 160 days and occurs from mid-May to mid-October. Precipitation, which averages 44 in. (inches) per year, generally is greatest during the spring and summer. October is normally the driest month of the year (table 2).

Convection thunderstorms are common during June and July. These storms may produce intense local rainfall that causes flooding in the narrow valley bottoms (U.S. Department of Commerce, 1977) and increases erosion in slope areas. Intense storms are rare over the entire Coal River basin, but they are frequent over small parts of the basin.

Table 2.--Honthly and annual precipltation at Madison, W.Va., water years 1975-84 (Data in inches]

\begin{tabular}{|c|c|c|c|c|c|c|c|c|c|c|c|c|c|}
\hline $\begin{array}{l}\text { Water } \\
\text { year }\end{array}$ & October & November & Decenber & January & rebruary & March & Apr11 & $\operatorname{may}$ & June & July & August & Septenber & Annual \\
\hline 1975 & 2.12 & 2.68 & 4.02 & 4.80 & 3.09 & 6.73 & 4.38 & 6.65 & 4.36 & 5.34 & 4.89 & 5.96 & 55.02 \\
\hline 1976 & 3.28 & 2.75 & 3.39 & 3.84 & 2.26 & 4.25 & .98 & 3.98 & 3.41 & 2.44 & 5.10 & 7.10 & 42.78 \\
\hline 1977 & 5.23 & 1.29 & 2.65 & 2.10 & 1.32 & 2.94 & 4.59 & 1.05 & 4.39 & 2.92 & 8.57 & 3.05 & 40.10 \\
\hline 1978 & 5.77 & 3.24 & 2.71 & 5.46 & 1.47 & 3.05 & 3.87 & 4.76 & 2.60 & 5.42 & 5.60 & .31 & 44.26 \\
\hline 1979 & 2.62 & 1.80 & 9.62 & 6.36 & 3.33 & 2.83 & 4.53 & 5.84 & 7.51 & 7.20 & 5.32 & 5.60 & 62.56 \\
\hline 1980 & 3.38 & 3.91 & 3.16 & 3.21 & 2.11 & 4.40 & 5.29 & 3.67 & 3.14 & 10.10 & 6.23 & 2.30 & 50.90 \\
\hline 1981 & 1.89 & 3.27 & 1.98 & 1.13 & 3.61 & 2.37 & 4.68 & 5.94 & 5.68 & 5.16 & 1.13 & 6.24 & 43.08 \\
\hline 1982 & 2.41 & 1.08 & 2.18 & 3.62 & 4.60 & 5.10 & 1.26 & 7.75 & 7.40 & 6.27 & 3.35 & 2.50 & 47.52 \\
\hline 1983 & 2.84 & 4.25 & 2.62 & 1.46 & 2.50 & 2.21 & 3.71 & 6.15 & 5.18 & 1.81 & 3.12 & 1.80 & 37.65 \\
\hline 1984 & 6.38 & 3.90 & 2.96 & 1.19 & 3.01 & 3.47 & 5.15 & 5.36 & 3.23 & 6.13 & 4.55 & 1.20 & 46.53 \\
\hline $\begin{array}{l}\text { Average } \\
\text { 1975-84 }\end{array}$ & 3.59 & 2.82 & 3.53 & 3.32 & 2.73 & 3.74 & 3.85 & 5.12 & 4.69 & 5.28 & 4.78 & 3.61 & 47.04 \\
\hline $\begin{array}{l}\text { Norma1 } \\
1951-80\end{array}$ & 2.66 & 3.01 & 3.35 & 3.47 & 3.11 & 4.17 & 3.80 & 4.11 & 4.10 & 4.87 & 3.84 & 3.41 & 43.90 \\
\hline
\end{tabular}

\section{DATA COLLECTION}

Collection of hydrologic data in the Coal River basin began in October 1974, and ended in September 1984. Locations of all datacollection sites are shown in figure 1. Data-collection sites are 1 isted by site number in table 1 . All suspended-sediment and streamflow data were published annually (Embree and others, 1983-85; U.S. Geological Survey, 1976-82). However, records of suspended-sediment data for the study period at the Little Coal River at Julian (site 5) were revised and published in the 1983 Annual Report. Suspended-sediment data for the 1983 and 1984 water years were published in the report, "Water Resources Data--West Virginia, Water Year 1984" (Embree and others, 1985). 
Collection of suspended-sediment data upstream and downstream from highway construction in Trace Fork basin started in July 1980. Site locations are shown in figure 3. Daily suspended-sediment discharge computed for the unaffected Trace Fork at Ruth subbasin (site 1) and the total Trace Fork basin downstream from Dryden Hollow at Ruth (site 2) for the period July 1980 through September 1982 are published in the report, "Water Resources Data - West Virginia, Water Year 1982" (Embree and others, 1983). Data for the 1983 and 1984 water years are published in the report, "Water

Resources Data--West Virginia, Water Year 1984" (Embree and others, 1985).

Daily suspended-sediment samples were collected at all sites in the Coal River basin using standard U.S. Geological Survey wading or bridge mounted depth-integrating samplers (US-D49, USDH59). Additional samples were collected manually during low and high flows to obtain data throughout the full range of flow. Sediment transported between sampler intake nozzles and the streambed was not sampled during the study because of sampler limitations. No bed-material samples were collected during the study.

Suspended-sediment concentrations, expressed in milligrams per liter, were determined by the dry-weight method outlined by Guy (1969), and daily suspended-sediment loads and yields were computed by techniques described by Porterfield (1972). The turbidity of all sediment samples was measured nephlometrically in the laboratory, and all sediment samples were analyzed for specific conductance in the laboratory.

Water-quality data were collected at each site in the study area. Properties measured periodically were specific conductance, $\mathrm{pH}$, air temperature, water temperature, turbidity, and, occasionally, dissolved oxygen. Samples for standard complete laboratory analysis and particle-size determinations were collected at some sites. The water-quality data are published annually (Embree and others, 1983-85, and U.S. Geologica1 Survey, 1976-82).

Precipitation data in the study area were obtained from National Oceanic Atmospheric Administration (NOAA) stations at Madison, Dry Creek, and Charleston Airport (U.S. Department of Commerce, 1974-84). Madison and Dry Creek are in the Coal River basin, and Charleston is about $10 \mathrm{mi}$ northeast of the basin (fig.1). Daily precipitation also was measured downstream from Dryden Hollow at Ruth (fig.3) in Trace Fork basin from July 1980 through September 1984 (see Appendix). 


\section{PRECIPITATION AND RUNOFF}

Annual precipitation recorded at the three NOAA sites from 1975 to 1984 are similar in amount and areal distribution throughout the study area (fig. 4). Because of central location and similarity of recorded data to all other precipitation stations in the study area, the precipitation data at Madison were used as most representative of precipitation in the Coal River basin. Month1y and annual precipitation data during the study period for Madison are shown in table 2; departure of annual precipitation data from the 1951-80 normal (long-term average) values is shown in figure 5. Monthly departures can be obtained by comparing the specific value to the corresponding monthly value from the normal (1951-80) in table 2. The largest above- and below-normal departures of annual precipitation at Madison from 1975 to 1984 were 18.66 in. in 1979 and 6.25 in. in 1983, respectively. The largest above - and below-normal departures of monthly precipitation were 6.27 in. in December 1978 and 3.10 in. in September 1978, respectively.

Ten storms produced rainfall that exceeded 2 in. in 24 hours at Madison from 1975-84. Of the 10 storms, the most intense produced $2.90 \mathrm{in}$. and occurred on July 28, 1980; however, other intense local storms probably occurred elsewhere in ungaged areas of the basin during the study period.

The storm on July 28, 1980, produced 1.90 in. of rainfall at Ruth. Four storms produced more than 2.00 in. of rainfall in a 24 hour period at Ruth between July 1980 and September 1984. Two of the four storms produced more than 3.00 in. in a 24-hour period; the most intense storm, on August 2, 1983, produced 3.50 in.; and the storm of May 30, 1982 produced 3.26 in.

Runoff (streamflow) was computed by methods described in Rantz and others (1982) and published annually (Embree and others, 1983-85 and U.S. Geological Survey, 1976-82). Runoff data for the study period for Little Coal River at Julian, however, were revised based on streamflow measurements obtained after 1981, which better defined highflows, and were published in the report, "Water Resources Data--West Virginia, Water Year 1983," (Embree and others, 1984).

Average annual runoff from gaging stations in the Coal River basin for the 1975 through 1984 water years ranged from 18.89 in. at Coal River at Tornado (site 7) to 20.98 in. at Little Coal River at Julian (site 5 ), about 40 to 45 percent of the precipitation recorded at Madison. The remainder of precipitation was lost to evapotranspiration, interbasin transfer of water (diversion of mine drainage and pumpage), and (or) seepage to deep ground-water reservoirs. 


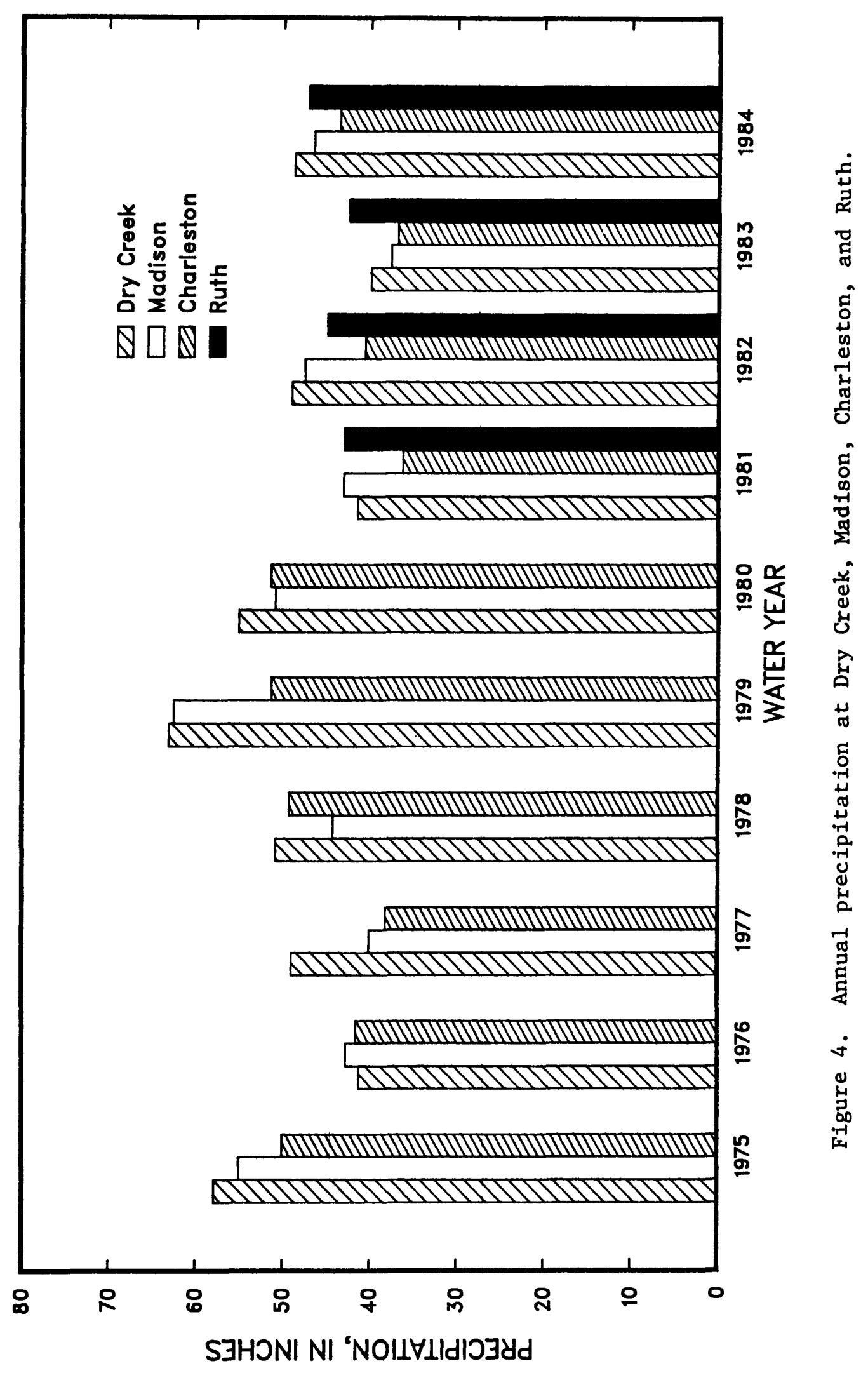




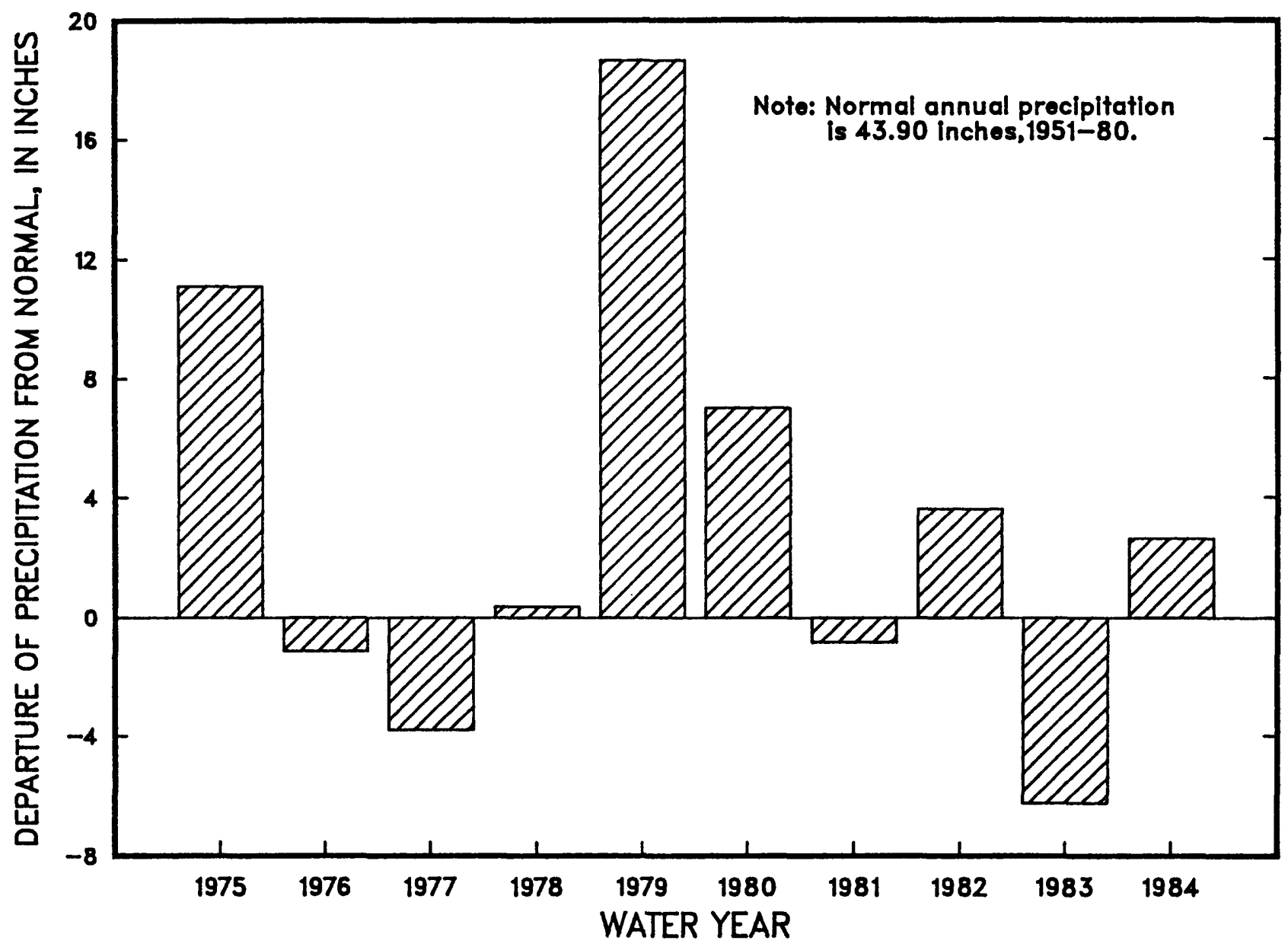

Figure 5. Departure from normal annual precipitation at Madison, water years 1975-84.

Annual precipitation at Madison and annual runoff at selected gaging stations are given in table 3; the maximum difference in average annual runoffs among the four sites is only $2.1 \mathrm{in}$. This difference is not significant because all or most of the difference is attributable to a combination of streamflow-measurement accuracy and stage-discharge variability, and to differences in basin physiography and precipitation distribution. Differences in annual runoff (table 3) generally correlate directly with differences in annual precipitation distribution in the study area. Land elevations, overland slopes, and precipitation generally increase from site 7 southward toward sites 3,5 , and 4 (fig.1). No runoff data for Big Coal River near Alum Creek (site 3) were collected for the 1982-84 water years. 
Table 3.--Annual precipitation at Madison and annual runoff at gaging sites in the Coal River basin, water years 1975-84 [Data in inches]

\begin{tabular}{|c|c|c|c|c|c|}
\hline \multirow[b]{2}{*}{$\begin{array}{l}\text { Water } \\
\text { year }\end{array}$} & \multirow{2}{*}{$\begin{array}{c}\text { Precipitation } \\
\text { at } \\
\text { Madison }\end{array}$} & \multicolumn{4}{|c|}{ Runoff } \\
\hline & & $\begin{array}{l}\text { Big Coal River near } \\
\text { Alum Creek (site } 3 \text { ) }\end{array}$ & $\begin{array}{l}\text { Little Coal River } \\
\text { at Danville (site 4) }\end{array}$ & $\begin{array}{l}\text { Little Coal River } \\
\text { at Julian (site } 5 \text { ) }\end{array}$ & $\begin{array}{l}\text { Coal River at } \\
\text { Tornado (site } 7 \text { ) }\end{array}$ \\
\hline 1975 & 55.02 & 27.31 & 25.35 & 26.81 & 25.28 \\
\hline 1976 & 42.78 & 13.36 & 13.81 & 15.84 & 13.40 \\
\hline 1977 & 40.10 & 15.98 & 16.48 & 16.79 & 15.40 \\
\hline 1978 & 44.26 & 23.14 & 20.68 & 22.98 & 20.45 \\
\hline 1979 & 62.56 & 30.91 & 30.23 & 32.55 & 28.12 \\
\hline 1980 & 50.90 & 24.63 & 25.64 & 26.02 & 23.12 \\
\hline 1981 & 43.08 & 15.07 & 15.15 & 15.13 & 14.92 \\
\hline 1982 & 47.52 & -- & 16.94 & 16.76 & 16.40 \\
\hline 1983 & 37.65 & -- & 17.18 & 18.09 & 15.56 \\
\hline 1984 & 46.53 & -- & 17.40 & 18.82 & 16.28 \\
\hline $\begin{array}{l}\text { 7-year } \\
\text { average }\end{array}$ & 48.39 & 21.49 & 21.05 & 22.30 & 20.10 \\
\hline $\begin{array}{l}\text { 10-year } \\
\text { average }\end{array}$ & 47.04 & -- & 19.89 & 20.98 & 18.89 \\
\hline
\end{tabular}

Continuous-streamflow records were collected for Trace Fork at Ruth and for Trace Fork downstream from Dryden Hollow at Ruth (sites 1 and 2 in figure 3). Runoff from July 1980 through September 1984 at site 1 upstream from the highway-construction area was 56.2 in., whereas runoff at site 2 downstream from construction was $61.0 \mathrm{in.}$ (table 4). The difference in runoff between the sites ( 4.8 in.) is within the accuracy of measurement and is considered insignificant. Results indicate that no significant trend or breaks in slope were found in the comparison of cumulative monthly runoff between the two sites. The relation of cumulative monthly runoff at site 1 to that at site 2 indicates that highway construction had little, if any, effect on runoff. Runoff for the study period for sites 1 and 2 was 28.5 and 31.0 percent of the precipitation recorded at Ruth (fig. 4). The remainder of precipitation was lost to evapotranspiration, interbasin transfer of water, and (or) seepage to deep ground-water reservoirs.

During the 51-month period of record, maximum dally mean discharges of 78 and $122 \mathrm{ft}^{3} / \mathrm{s}$ (cubic foot per second) at sites 1 and 2, respectively, were recorded on May 30, 1982. The instantaneous peak flow at site 1 was $260 \mathrm{ft}^{3} / \mathrm{s}$ on May 30,1982, and $430 \mathrm{ft}^{3} / \mathrm{s}$ at site 2 on July 10, 1980. From July 1980 through September 1984, daily streamflow averaged $2.72 \mathrm{ft} / \mathrm{s}$ for site 1 and $4.99 \mathrm{ft}^{3} / \mathrm{s}$ for site 2 . 
Table 4.--Annual precipitation at Dryden Hollow and annual runoff at gaging sites in the Trace Fork basin, water years 1980-84, in inches

(A11 numbers rounded to three significant figures)

\begin{tabular}{|c|c|c|c|}
\hline & & \multicolumn{2}{|c|}{ Runoff } \\
\hline $\begin{array}{l}\text { Water } \\
\text { years }\end{array}$ & $\begin{array}{c}\text { Precipitation } \\
\text { at } \\
\text { Dryden Hollow }\end{array}$ & $\begin{array}{c}\text { Trace Fork } \\
\text { at Ruth } \\
\text { (site 1) }\end{array}$ & $\begin{array}{c}\text { Trace Fork } \\
\text { downstream } \\
\text { Dryden Hollow } \\
\text { at Ruth (site 2) } \\
\end{array}$ \\
\hline • 1980 & 19.6 & 3.44 & 3.55 \\
\hline 1981 & 43.0 & 13.7 & 14.3 \\
\hline 1982 & 44.9 & 11.9 & 14.7 \\
\hline 1983 & 42.4 & 12.9 & 13.1 \\
\hline 1984 & 47.2 & 14.3 & 15.3 \\
\hline Total & 197 & 56.2 & 61.0 \\
\hline
\end{tabular}

*Partial water year (July - september 1980).

\section{SUSPENDED-SEDIMENT YIELD}

\section{Coal River Basin}

Estimates of annual and average annual suspended-sediment loads and yields for selected mainstem sites in the study areas for the period 1975 through 1984 are presented in table 5 . Sediment yields in (tons $/ \mathrm{mi}^{2} / \mathrm{in}$ ) (tons per square mile per inch) also were computed for comparison on a unit-runoff basis. Suspended-sediment yields given in table 5 are representative of 6 years of above-normal precipitation and 4 years of belownormal precipitation (fig. 5). Annual yields ranged from 113 to 1,000 tons $/ \mathrm{mi}^{2}$. The maximum annual yield at each site occurred in 1979 , when annual precipitation in the basin was highest (fig. 4). The lowest annual yields occurred in 1983 when annual precipitation was more than 6 inches below normal. No sediment data were collected at sites 3 and 5 for the 1982-84 water years.

The similarity of the suspended-sediment yields for all sites in table 5 indicates that suspended sediment from highway construction areas had an effect that was small relative to the effect of other land uses, such as mining and logging, on the mainstem of the Coal River. This probably results from the masking effects of large sediment loads contributed to the river from other sources in upstream reaches and from dilution of flow from highway construction areas by the large volume of water in the mainstem. 


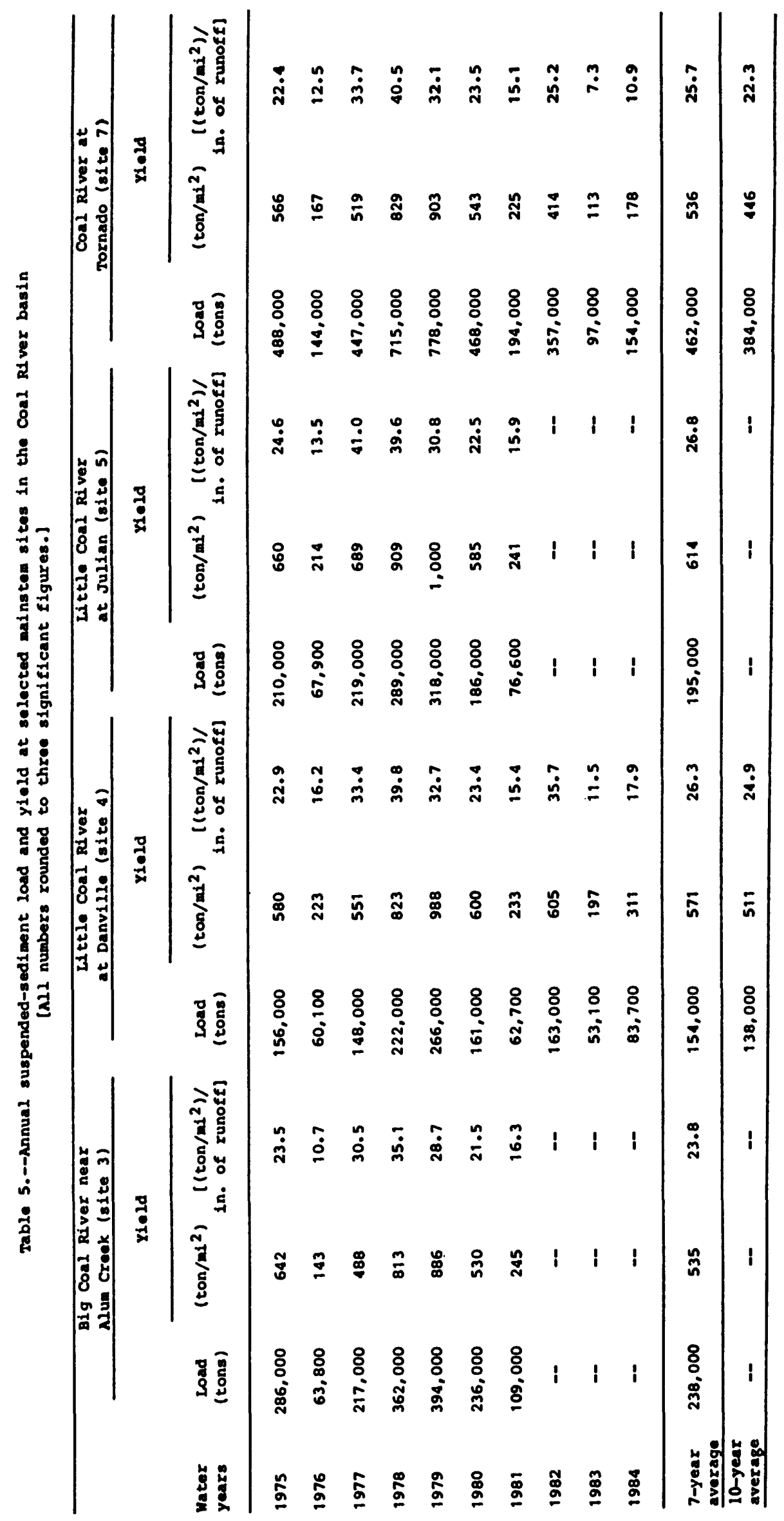


Sediment yields throughout the Coal River basin probably were also high during the 1973 and 1974 water years, when average annual precipitation at Madison (53 in.) was higher than normal. Average annual sediment yields during the 1973 and 1974 water years that were estimated for some of the subbasins affected by mining and logging, but not by highway construction, within the Coal River drainage (fig. 1) during this period were: Spruce Fork, 1,450 tons $/ \mathrm{mi}^{2}$; Pond Creek, 2,500 tons $/ \mathrm{mi}^{2}$; and Drawdy Creek, 2,500 tons $/ \mathrm{mi}^{2}$ (Bader and others, in press). Average annual sediment yield of the Little Coal River at Danville (site 4) was about 1,700 tons/mi ${ }^{2}$, compared to 800 tons $/ \mathrm{mi}^{2}$ for the Coal River at Tornado (site 7 ). In contrast, the average annual sediment yield at site 4 during water years 1975-84, was 511 tons $/ \mathrm{mi}^{2}$ (table 5) and the average annual yield at site 7 was only 446 tons $/ \mathrm{mi}^{2}$. It is evident that high suspended-sediment yields in the coal River system are derived from land uses other than highway construction, such as logging and mining.

Curves representing the suspended-sediment discharge and streamflow relation for two of the mainstem sites during water years 1975-84 are shown in figure 6. There is noticeable variability at site 7 depending on the period of analysis. The curve for the 1982-84 period was a period after construction was completed, but the low annual precipitation for the 1983 water year probably is the most significant reason for this offset. These regression lines for each site show the relation among the variables and should not be used to predict values.

The interim progress report of Downs and Appel (1984) that analyzed the 1975-81 water years revealed that the positions and the slopes of the curves for sites 3, 4, and 5 were quite similar, which indicates that the relations of streamflow and suspended-sediment load at the Big Coal near Alum Creek, Little Coal at Danville, and Little Coal at Julian are nearly the same. The slope of the line of relation for site 7 is nearly the same as that of site 4 but is shifted to the right. This probably reflects sediment deposition as a result of reduced water velocity in a 6-mile long reach of pooled water at site 7 . Larger volumes of streamflow are required to transport an equal amount of sediment at site 7 than at sites 3,4 , and 5 .

If highway construction significantly affects suspended-sediment yield in the Coal River basin, the relation between suspended-sediment yield and runoff over time should change. The interim progress report showed no significant change in cumulative annual suspended-sediment yield over time (1975-81 water years) for all four mainstem sites. The data collected at sites 4 and 7 for the 1982-84 water years support this, as no significant offset is shown in figure 7 .

The relations among cumulative annual suspended-sediment yield and runoff at sites 4 and 7 are shown in figure 8 . Similarly, no significant breaks or changes in slope of the relations for sites on the mainstem of the Coal River occur as would be expected if large amounts of sediment relative to the total load were contributed from the construction area. However, this does not imply that highway construction did not contribute suspended sediment to the Coal River. The curves show that the large volume of sediment contributed from other upstream sources and the volume of water in the Coal River simply masks the amount contributed by highway construction. Data were not available to differentiate sediment yields derived from highway construction from the normal annual suspended-sediment yield of the Coal River basin. 


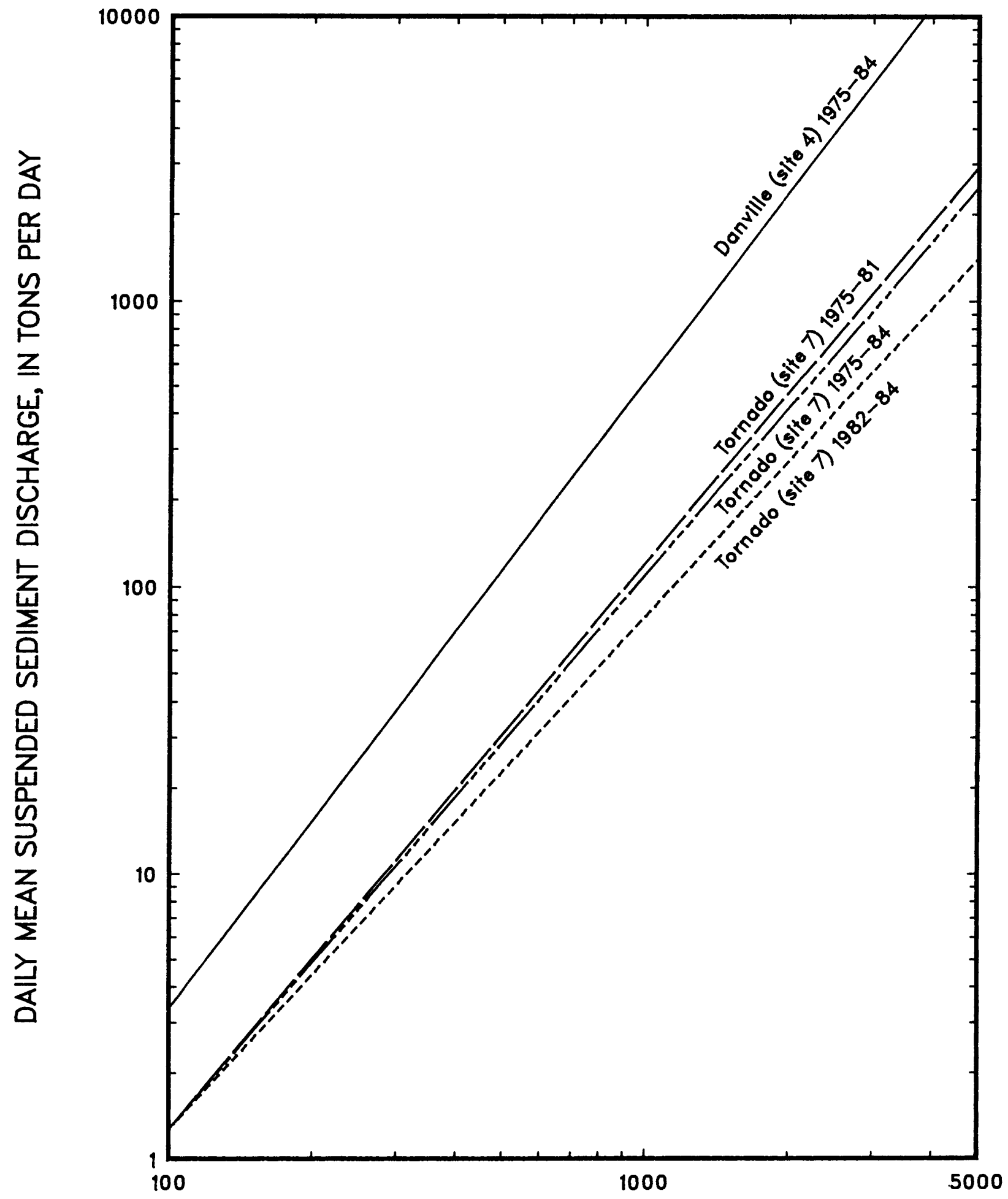

DAILY MEAN STREAMFLOW, IN CUBIC FEET PER SECOND

Figure 6. Relation between dally suspended-sediment discharge and streamflow at sites in the Coal River basin, water years 1975-84. 


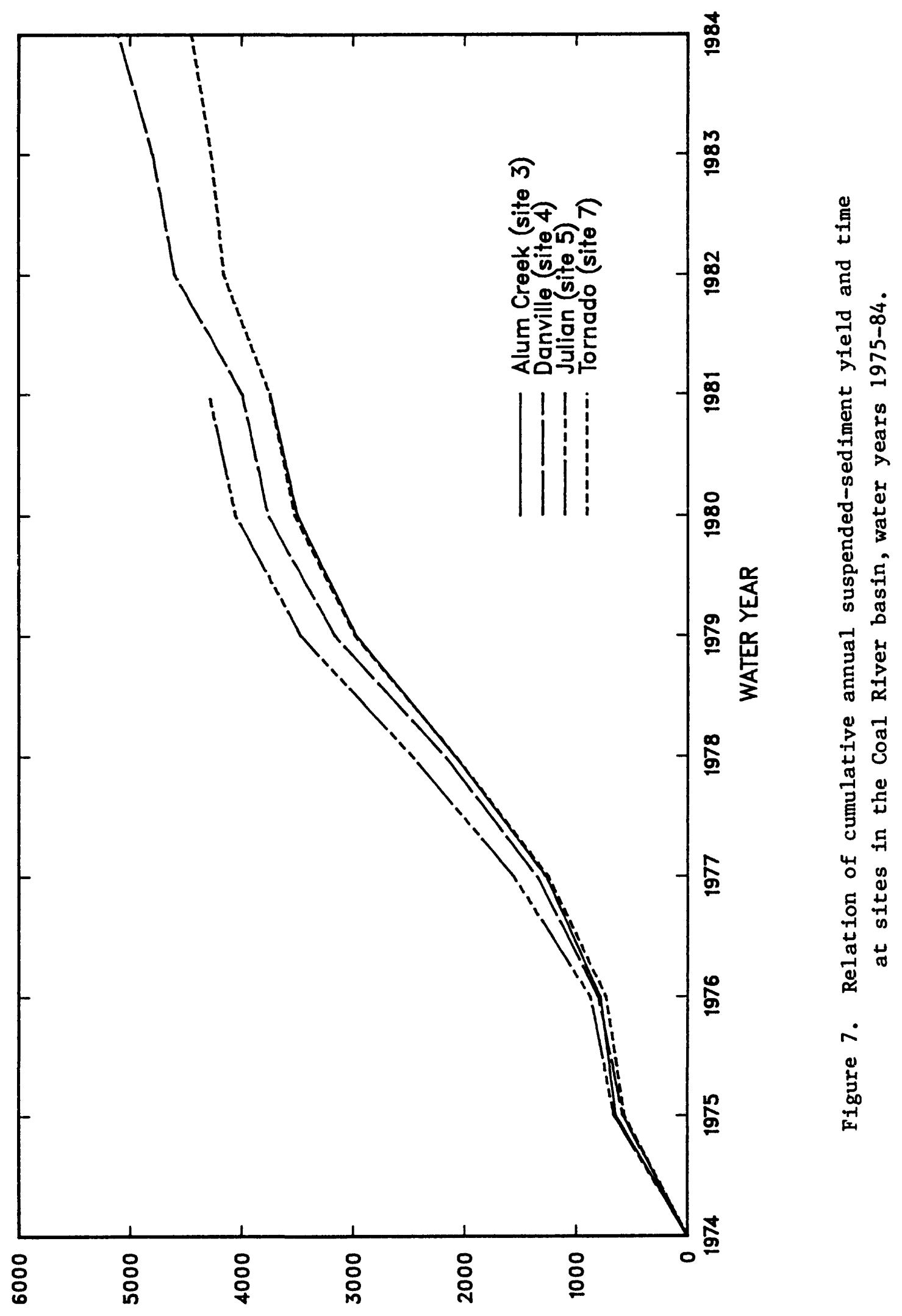

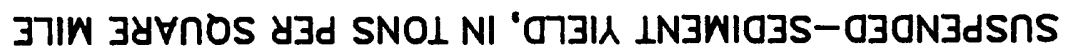




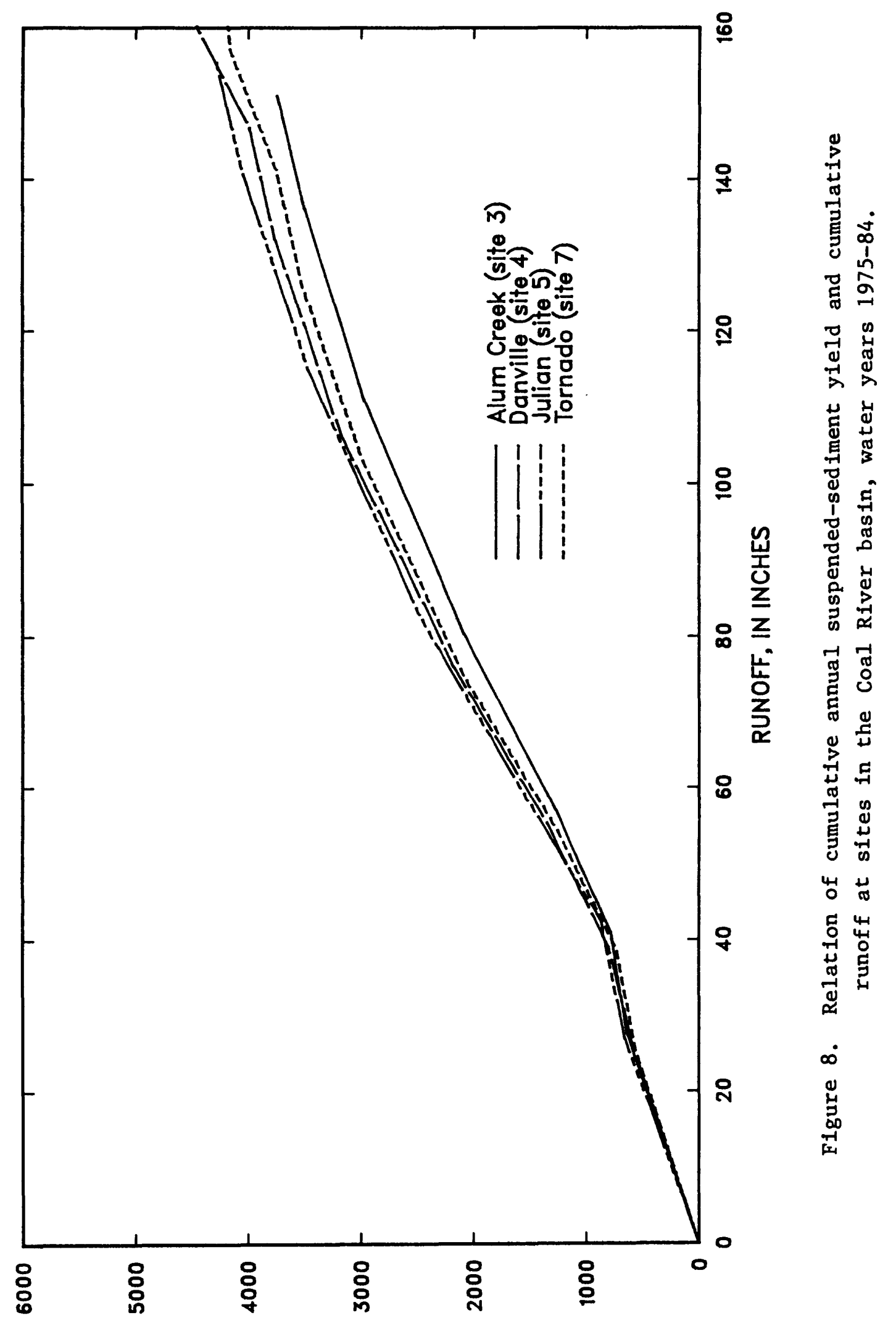

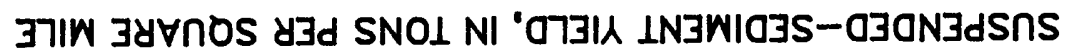




\section{Trace Fork Basin}

In the Trace Fork basin, the sediment load transported at site 2, which is downstream from the areas affected by highway construction, was more than three times greater than that at site 1 , which is upstream from the areas affected by highway construction. To determine how much of the sediment load at site 2 (table 6 ) was derived from the construction area, it was necessary to estimate the normal sediment load at site 2 . The normal sediment load can be estimated as follows:

$$
\operatorname{Sed}_{\mathrm{N} 2}=\frac{\mathrm{A}_{2} \times \operatorname{Sed}_{1}}{\mathrm{~A}_{1}}
$$

where:

$$
\begin{aligned}
& \text { Sed }_{\mathrm{N} 2}=\text { estimated normal sediment load (tons) at site } 2, \\
& \mathrm{~A}_{2}=\text { the drainage area }\left(\mathrm{mi}^{2}\right) \text { at site } 2, \\
& \mathrm{~A}_{1}=\text { the drainage area }\left(\mathrm{mi}^{2}\right) \text { at site } 1 \text {, and } \\
& \text { Sed }_{1}=\text { the sediment load (tons) at site } 1 .
\end{aligned}
$$

The estimated normal load $\left(\operatorname{Sed}_{\mathrm{N} 2}\right.$ ) is an indication of the normal sediment load from Trace Fork downstream from Dryden Hollow at Ruth (site 2), based on measured loads from the unaffected areas above site 1 . The difference between the measured load and the estimated normal load at site 2 may be directly attributed to highway construction. Estimates of monthly normal suspended-sediment loads at site 2 and the load contribution from the highway construction area are shown in figure 9. The greatest monthly load contributed from the construction area (approximately 760 tons) was discharged in July 1980.

The sediment discharge during the 51 -month period at site 1 was 2,100 tons (a yield of 746 tons $/ \mathrm{mi}^{2}$ ), whereas the discharge at site 2 was 6,970 tons (a yield of 1,480 tons $/ \mathrm{mi}^{2}$ ) as shown in table 6 . The normal sediment discharge at site 2, computed from equation (a), was 3,520 tons. Therefore, the probable contribution from the highway construction area $\left(0.29 \mathrm{mi}^{2}\right)$ was about 3,450 tons, which is equivalent to about 11,900 tons $/ \mathrm{mi}^{2}$, or about 2,800 (tons $/ \mathrm{mi}^{2}$ ) $/ \mathrm{yr}$. This value from the construction area alone is only twice as much as the overall basin output in Turtle Creek 1,400 (tons $/ \mathrm{mi}^{2}$ )/yr, where 60 percent of the channel was altered or relocated (Chisholm and Downs, 1978).

The sediment discharge during the same 51 -month period at Little Coal River at Danville (site 4), which is upstream from areas affected by highway construction, was about 1,570 (tons $/ \mathrm{mi}^{2}$ ) $/ \mathrm{yr}$. The major land uses upstream from site 4 are mining and logging. The suspended-sediment yield from the Trace Fork basin, which is directly affected by highway construction, was no higher than yields from other sites in the Coal River basin that are affected by other land uses, such as logging and mining. 


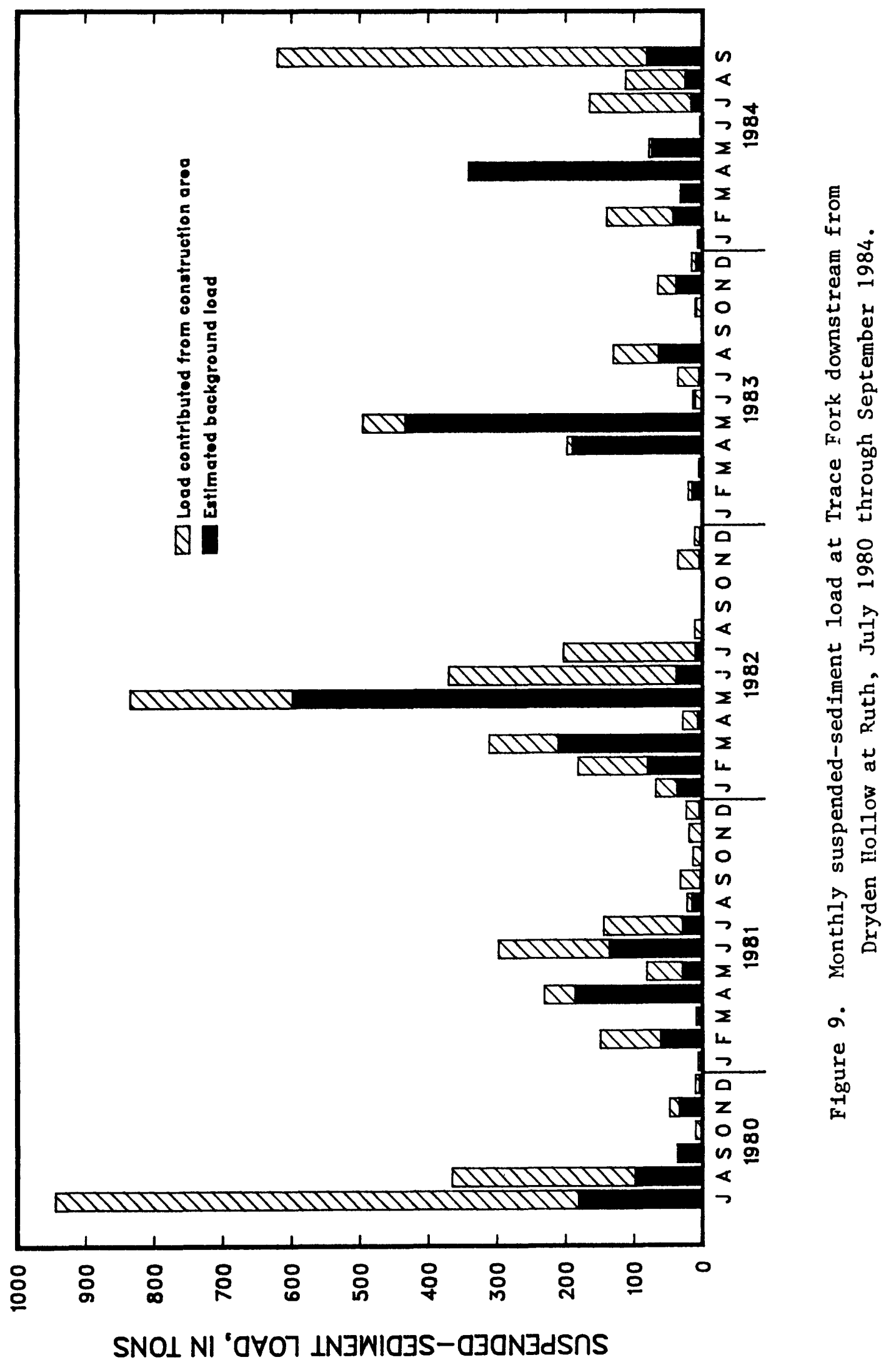


Table 6.--Annual suspended-sediment load and yield for Trace Fork sites

[All numbers rounded to three significant figures.]

\begin{tabular}{|c|c|c|c|c|c|c|}
\hline \multirow[b]{3}{*}{$\begin{array}{l}\text { Watex } \\
\text { year }\end{array}$} & \multicolumn{3}{|c|}{ Trace Fork at Ruth (site 1) } & \multirow[t]{2}{*}{ Trace Fork } & \multicolumn{2}{|c|}{$\begin{array}{l}\text { downstream from Dryden Hollow } \\
\text { at Ruth (site 2) }\end{array}$} \\
\hline & \multirow[b]{2}{*}{$\begin{array}{l}\text { Load } \\
\text { (tons) }\end{array}$} & \multicolumn{2}{|c|}{ Yield } & & \multicolumn{2}{|c|}{ Yield } \\
\hline & & $\left(\operatorname{ton} / \mathrm{mi}^{2}\right)$ & $\begin{array}{l}{\left[\left(\text { ton } / \mathrm{mi}^{2}\right) /\right.} \\
\text { in. of runoff] }\end{array}$ & $\begin{array}{l}\text { Load } \\
\text { (tons) }\end{array}$ & $\left(\right.$ ton/mi $\left.{ }^{2}\right)$ & $\begin{array}{l}{\left[\left(\text { ton } / \mathrm{mi}^{2}\right) /\right.} \\
\text { in. of runof }]\end{array}$ \\
\hline .1980 & 193 & 68.4 & 19.9 & 1,350 & 285 & 80.6 \\
\hline 1981 & 303 & 108 & 7.86 & 1,040 & 220 & 15.3 \\
\hline 1982 & 592 & 210 & 17.7 & 2,070 & 438 & 29.8 \\
\hline 1983 & 439 & 156 & 12.1 & 934 & 198 & 15.1 \\
\hline 1984 & 575 & 204 & 14.3 & 1,580 & 335 & 21.8 \\
\hline Total & 2,100 & 746 & 71.9 & 6,970 & 1,480 & 163 \\
\hline
\end{tabular}

- Partial water year (July-September 1980).

Four major storms with rainfall greater than 2 inches within 24 hours at Ruth occurred from July 1980 through September 1984 and produced runoff that carried 24 and 31 percent of the total suspended-sediment load for the 51 -month study period at sites 1 and 2 , respectively. Figure 10 is a cumulative plot for both Trace Fork sites for the study period. Construction phases and progress also are shown. Noticeable increases in sediment yield in figure 10 show the result of major storms within the basin.

The storm of July 9 and 10, 1980 (total of 3.25 inches of rainfal1) contributed 627 tons of suspended sediment, which was nearly half of the 3 -month total measured in the first water year and about 9 percent of the 51-month study total. This storm occurred during the first phase of construction in the basin. The storm of May 29 and 30,1982 (total of 3.34 in. of rainfal1) contributed 833 tons of suspended sediment, which was 12 percent of the 51 -month study total and 40 percent of the total for water year, and nearly 90 percent of the total for the following 1983 water year. This storm occurred immediately after the cleanup of the first phase of construction. Major storms can drastically affect suspended-sediment yields 


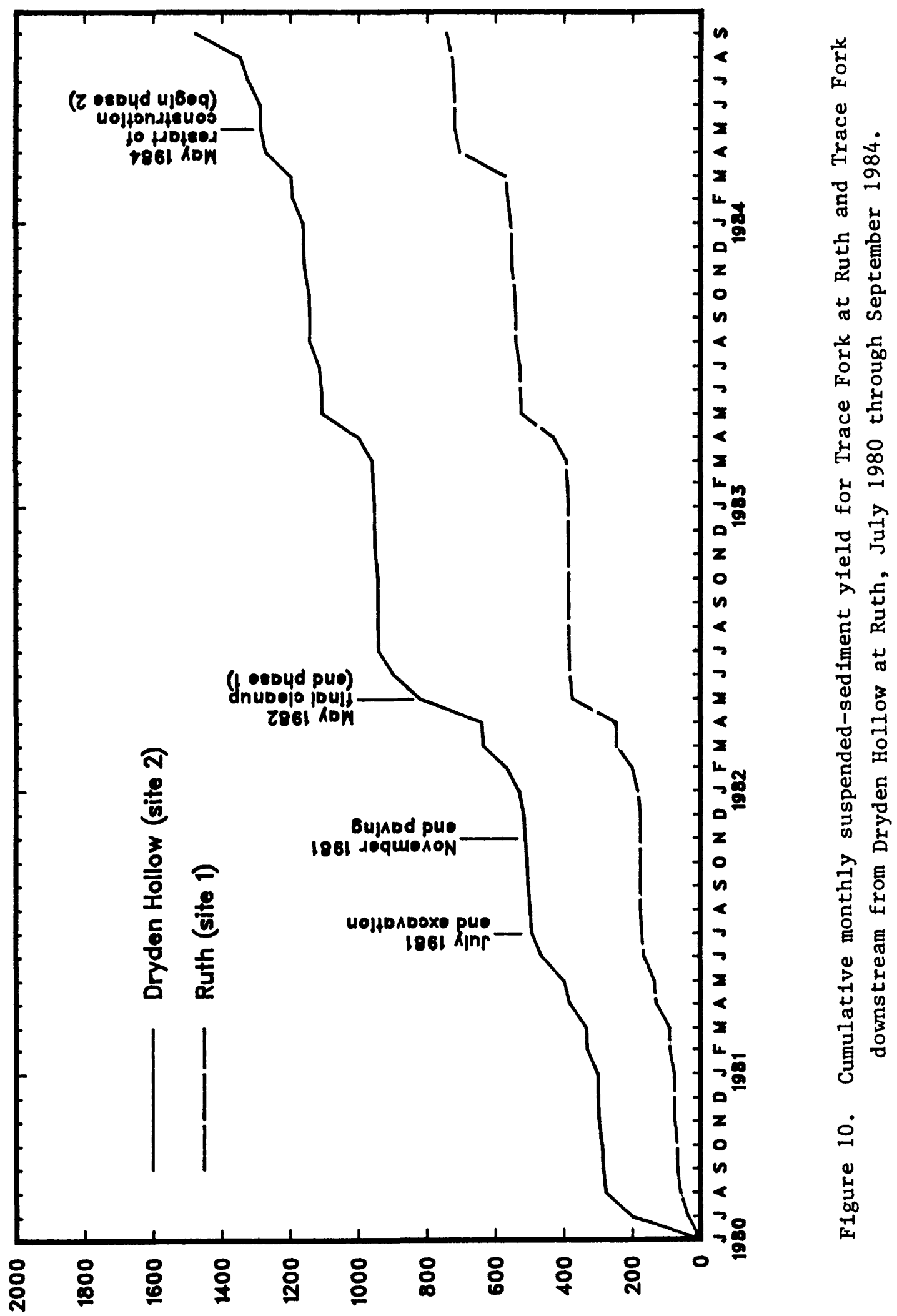

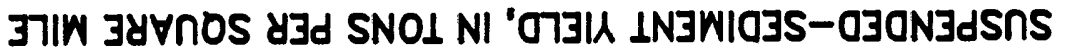


until revegetated areas are stabilized. The storm of August 1 and 2, 1983 (total of 3.50 in. of rainfall--the largest rainfall during the study) contributed 114 tons of suspended sediment, which was only 12 percent of the total for the water year. This storm followed a wet period (July 18-31) in which 3.26 in. of rain fell and saturated the soil. The load from this storm appears low, but this was during a time of reclamation between the two phases of highway construction and precipitation totals for 10 of the 14 months prior to this storm were below normal. The spring storms during April and May could have removed the majority of available suspended sediment, thereby causing low yields for the storm of August 1 and 2. The storm of September 3 and 4, 1984 (total 2.45 in. of rainfall) contributed 617 tons of suspended sediment, which was nearly 40 percent of the total for the water year. This storm occurred during the second phase of highway construction and just prior to the end of data collection.

Small or moderate amounts of precipitation can cause large suspendedsediment concentrations, depending on intensity of the storm and degree of soil disturbance and saturation. For example, 0.82 in. of precipitation recorded during the storm of September 15, 1981, produced an instantaneous sediment concentration of $7,520 \mathrm{mg} / \mathrm{L}$ (milligrams per 1iter) and a daily sediment load of 30 tons at site 2. Also the storm of April 22 and 23, 1984 (total of 1.89 in. of rainfall) caused an abrupt change in the cumulative plot (fig. 10) as did the three storms in May 1983 (each less than 1.5 in. of rainfall).

Figure 11 shows the relation of cumulative monthly suspended sediment to cumulative monthly streamflow for site 2. Three major storms--July 1980, May 1982, and September 1984--account for the abrupt changes in this plot. Note that the lines of correlation are parallel and that they are offset because of the contribution of these major storms.

The maximum daily mean suspended-sediment concentration during the 51 -month study period at site 2 was $2,500 \mathrm{mg} / \mathrm{L}$ on July 10 of the July $9-10,1980$ storm, which was during the first phase of highway construction in the basin. The maximum daily mean concentration at Little Coal River at Danville (site 4, drainage area of $269 \mathrm{mi}^{2}$ ) for the same 51 months was $2,490 \mathrm{mg} / \mathrm{L}$ on February 9, 1982, and the mean daily concentration on July 9 of the July 9 - 10, 1980 storm was $2,090 \mathrm{mg} / \mathrm{L}$. These daily mean suspendedsediment concentrations are not excessive for streams in southern West Virginia. For example, the maximum mean daily suspended-sediment concentration from June 1974 through September 1978 was 2,670 mg/L at Clear Fork at Clear Fork (drainage area $124 \mathrm{mi}^{2}$ ), and 2,200mg/L from July 1973 through September 1979 at Guyandotte River near Baileysville (drainage area $308 \mathrm{mi}^{2}$ ) (U.S. Geological Survey, 1978 and 1979).

Curves representing the suspended-sediment discharge and streamflow relation for both sites in the Trace Fork basin from July 1980 through September 1984 are shown in figure 12. These regression lines for each site show the relation among the variables and should not be used to predict values. 


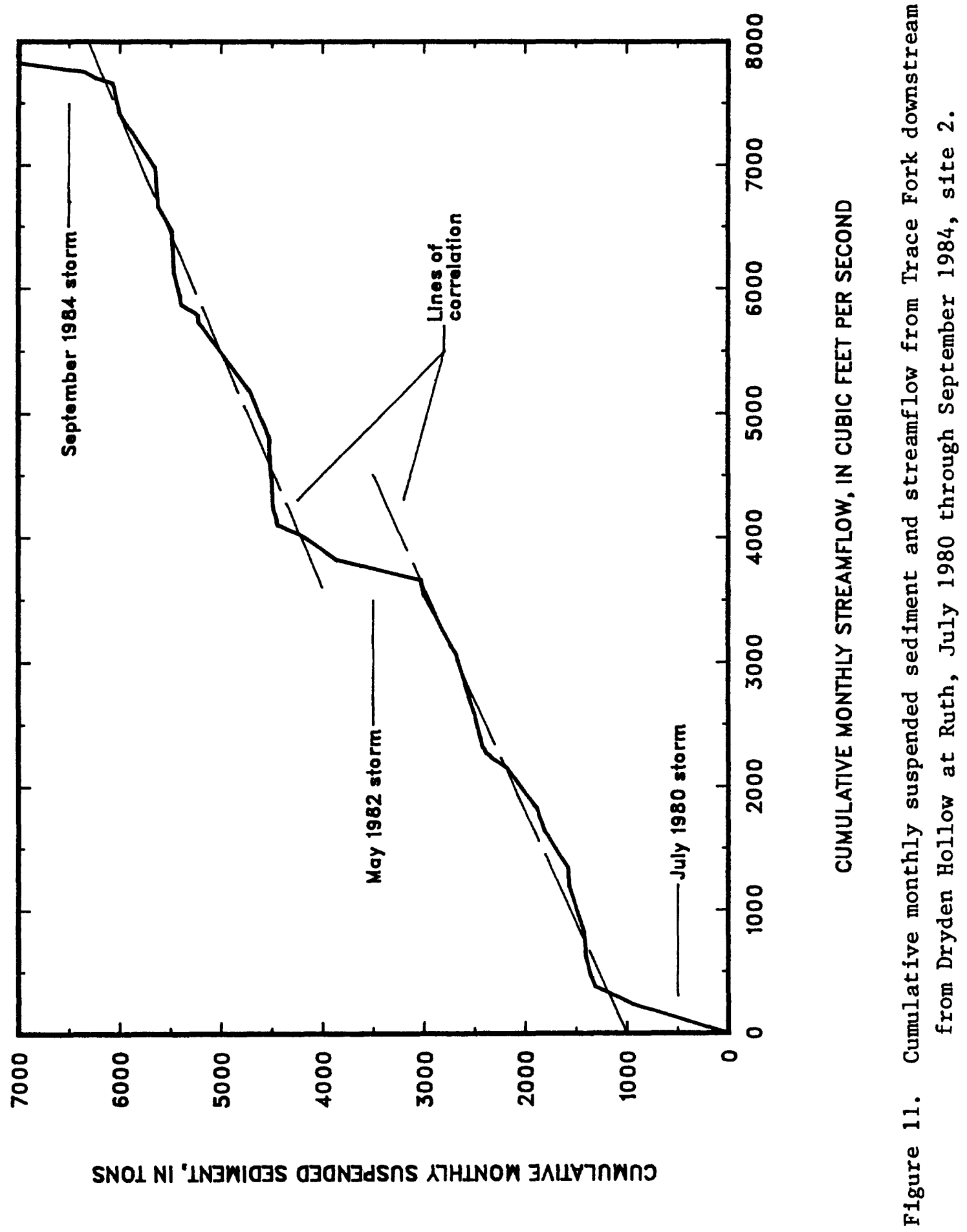




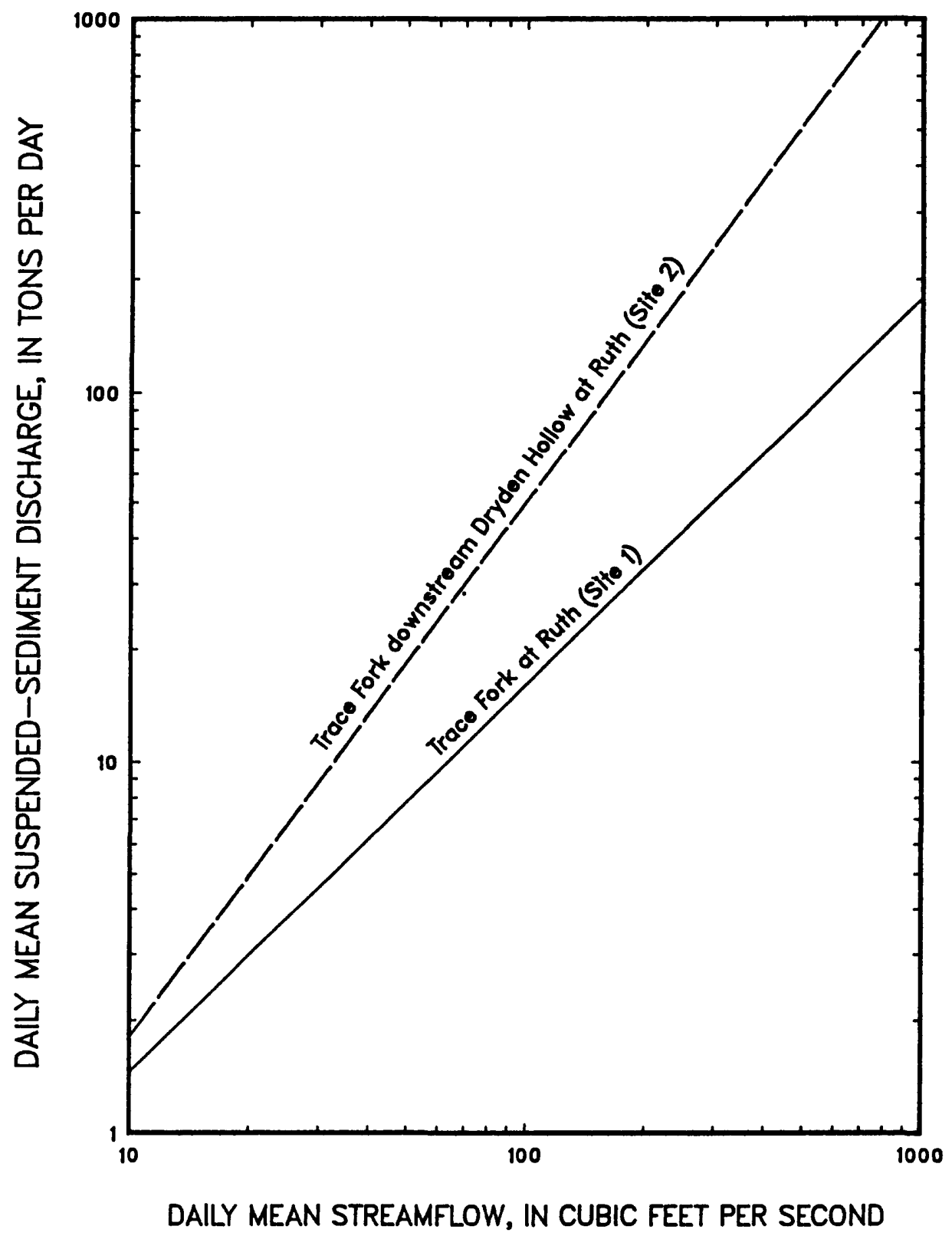

Figure 12. Relation between daily suspended-sediment discharge and streamflow at sites in the Trace Fork basin, July 1980 through September 1984. 


\section{SUMMARY AND CONCLUSIONS}

Areas in the Little Coal and Big Coal River subbasins within the Coal River basin, and in Trace Fork basin of southern West Virginia, were disturbed by construction of Appalachian Corridor G--a four-lane highway. Highway construction occurred during 1972-75 along Turtle Creek downstream from Danville in the Little Coal River basin, and during 1979-82 downstream from Julian in the Little Coal River, in the Big Coal River and in the Trace Fork basins. During the latter period, approximately $18 \mathrm{million}^{\mathrm{yd}^{3}}$ of material was excavated along a 12 -mile segment of roadway between Julian and the confluence of the Little and Big Coal Rivers.

From 1975 through 1984, daily suspended-sediment and runoff data were collected at mainstem sites on the Big Coal, Little Coal, and Coal Rivers to determine sediment contribution from highway-construction areas in the Coal River basin. Increases in suspended-sediment loads and runoff at the mainstem sites solely because of highway construction were difficult to detect. During the water years 1975-84, the average suspended sediment yield of the Little Coal River at Danville, upstream from highway construction, was 511 (tons $/ \mathrm{mi}^{2}$ )/yr. The yield at Coal River at Tornado downstream from construction--the lowermost downstream site in the Coal River basin--was 446 (tons $/ \mathrm{mi}^{2}$ )/yr.

From July 1980 through September 1984, runoff and suspended-sediment data were collected upstream and downstream from areas affected by highway construction in Trace Fork basin to determine sediment contribution from construction areas in the basin. Approximately $4.8 \mathrm{million}^{\mathrm{yd}^{3}}$ of material was excavated in a 2.0-mile segment of highway in Dryden Hollow--a major tributary to Trace Fork.

Unit runoff from the disturbed area in the Trace Fork basin was nearly the same as that from the unaffected or undisturbed parts of the basin. Suspended-sediment loads, however, were much higher in Trace Fork downstream from the construction area. Normal sediment load at Trace Fork downstream from Dryden Hollow--the downstream site--for the 51-month period was estimated to be 3,520 tons; the measured load was 6,970 tons. Four major storms with rainfall greater than 2 in. within 24 hours at Ruth occurred from July 1980 through September 1984 and produced runoff that carried about 31 percent of the total suspended sediment discharged from the basin during the 51 -month study period.

The suspended-sediment yield for Trace Fork downstream from Dryden Hollow at Ruth (site 2) during the study period was about 1,480 tons $/ \mathrm{mi}^{2}$, and the major land disturbance upstream from this site was highway construction. In contrast, the suspended-sediment yield for Little Coal River at Danville (site 4) (above highway construction) was 1,570 tons $/ \mathrm{mi}^{2}$ during the same period, and the major land disturbances upstream from this site were logging and mining. 
Conclusions from this study are:

1. The similarity of the suspended-sediment yields for all sites on the Coal River mainstem indicate that increases in suspendedsediment yield from highway construction areas are difficult to detect on the mainstem of the Coal River. This probably results from the masking effects of large sediment loads contributed to the river from other sources in upstream reaches, and from dilution of flow from highway construction areas by the large volume of water in the mainstem.

2. The suspended-sediment yield (tons $/ \mathrm{mi}^{2}$ ) for the Trace Fork downstream Dryden Hollow site (downstream from highway construction), was nearly double the yield for the Trace Fork at Ruth site (upstream from highway construction) for the period July 1980 through September 1984. Approximately 3,450 tons of suspended sediment was derived from the $0.29 \mathrm{mi}^{2}$ area affected by. highway construction.

3. The maximum daily mean suspended-sediment concentration $(2,500 \mathrm{mg} / \mathrm{L})$ during the 51 -month study in the Trace Fork basin-associated with highway construction--was no greater than maximum daily means for other sites in the Coal River basin or for other southern West Virginia streams.

4. Major storms can drastically affect suspended-sediment yields until revegetated areas are stabilized. Small or moderate amounts of precipitation can cause large suspended-sediment concentrations, depending on intensity of the storm and degree of soil disturbance, and degree of saturation. 


\section{SELECTED REFERENCES}

Bader, J. S., Chisholm, J. L., Downs, S. C., and Morris, F. O., in press, Water resources of the Coal River basin, West Virginia: West Virginia Geological and Economic Survey, River Basin Bulletin 5.

Cardwe11, D. H., Erwin, R. B., and Woodward, H. P., compilers, 1968, Geologic map of West Virginia: West Virginia Geological and Economic Survey, 1 sheet, scale 1:250,000.

Chisholm, J. L., and Downs, S. C., 1978, Stress and recovery of aquatic organisms as related to highway construction along Turtle Creek, Boone County, West Virginia: U.S. Geological Survey Water-Supply Paper 2055, $40 \mathrm{p}$.

Downs, S. C., and Appe1, D. H., 1986, Progress report on the effects of highway construction on suspended-sediment discharge in the Coal River and Trace Fork, West Virginia, 1975-81: U.S. Geological Survey WaterResources Investigations Report 84-4275, 20 p.

Eckhardt, D. A., 1976, Sediment discharge from an area of highway construction, Applemans Run basin, Columbia County, Pennsylvania: U.S. Geological Survey Water-Resources Investigations Report 76-111, 25 p.

Embree, W. N., Friel, E. A., Ehlke, T. A., and Ward, S. M., 1983, Water resources data for West Virginia, Water Year 1982: U.S. Geological Survey Water-Data Report WV-82-1, 342 p.

Embree, W. N., Friel, E. A., Taylor, F. M., and Ehlke, T. A., 1984, Water resources data for West Virginia, Water Year 1983: U.S. Geological Survey Water-Data Report WV-83-1, 234 p.

Embree, W. N., Friel, E. A., and Taylor, F. M., 1985, Water resources data for West Virginia, Water Year 1984: U.S. Geological Survey Water-Data Report WV-84-1, 323 p.

Fenneman, N. M., and Johnson, D. W., 1946, Physical divisions of the United States: U.S. Geological Survey map prepared in cooperation with Physiographical Commission, U.S. Geological Survey, scale 1:7,000,000. (Reprinted 1964).

Guy, H. P., 1969, Laboratory theory and methods for sediment analysis: U.S. Geological Survey Techniques of Water-Resources Investigations, Book 5 , Chapter $\mathrm{C1}, 58 \mathrm{p}$.

McColloch, J. S., and Lessing, Peter, 1980, Land-use statistics for West Virginia: West Virginia Geological and Economic Survey, Environmental Geology Bulletin No. 18A, 59 p. 
Porterfield, George, 1972, Computations of fluvial-sediment discharge: U.S. Geological Survey Techniques of Water-Resources Investigations, Book 3 , Chapter C3, 66 p.

Rantz, S. E., and others, 1982, Measurement and computation of streamflow, Volume 2, Computation discharge: U.S. Geological Survey Water-Supply Paper 2175, 347 p.

U.S. Department of Commerce, 1974-84, Climatological data, annual summary, West Virginia: National Oceanic and Atmospheric Administration, Environmental Data Service, Annual Summaries, Volumes 82-92, Number 13.

--1977, Climate of West Virginia: National Oceanic and Atmospheric Administration, Environmental Data Service, Climatography of the United States, No. $60,19 \mathrm{p}$.

-.-1982, Monthly normals of temperature, precipitation, and heating and cooling degree days 1951-80, West Virginia: National Oceanic and Atmospheric Administration, Environmental Data Service, Climatography of the United States No. $81,8 \mathrm{p}$.

U.S. Geological Survey, 1976-82, Water resources data for West Virginia: U.S. Geological Survey Water-Data Report, Water Years 1975-81 (published annually).

Van Houten, D. G., Childs, F. D., Teets, C. C., Estepp, Ronald, and Doonan, F. A., 1981, Soil survey of Kanawha County, West Virginia: Soil Conservation Service, 111 p. 


\section{APPENDIX--Daily Precipitation Data}

Daily precipitation from July 1980 through September 1984 downstream from Dryden Hollow at Ruth, W. Va. (station 03198022, site 2). Gage read by observer once per day. (Data in inches) 


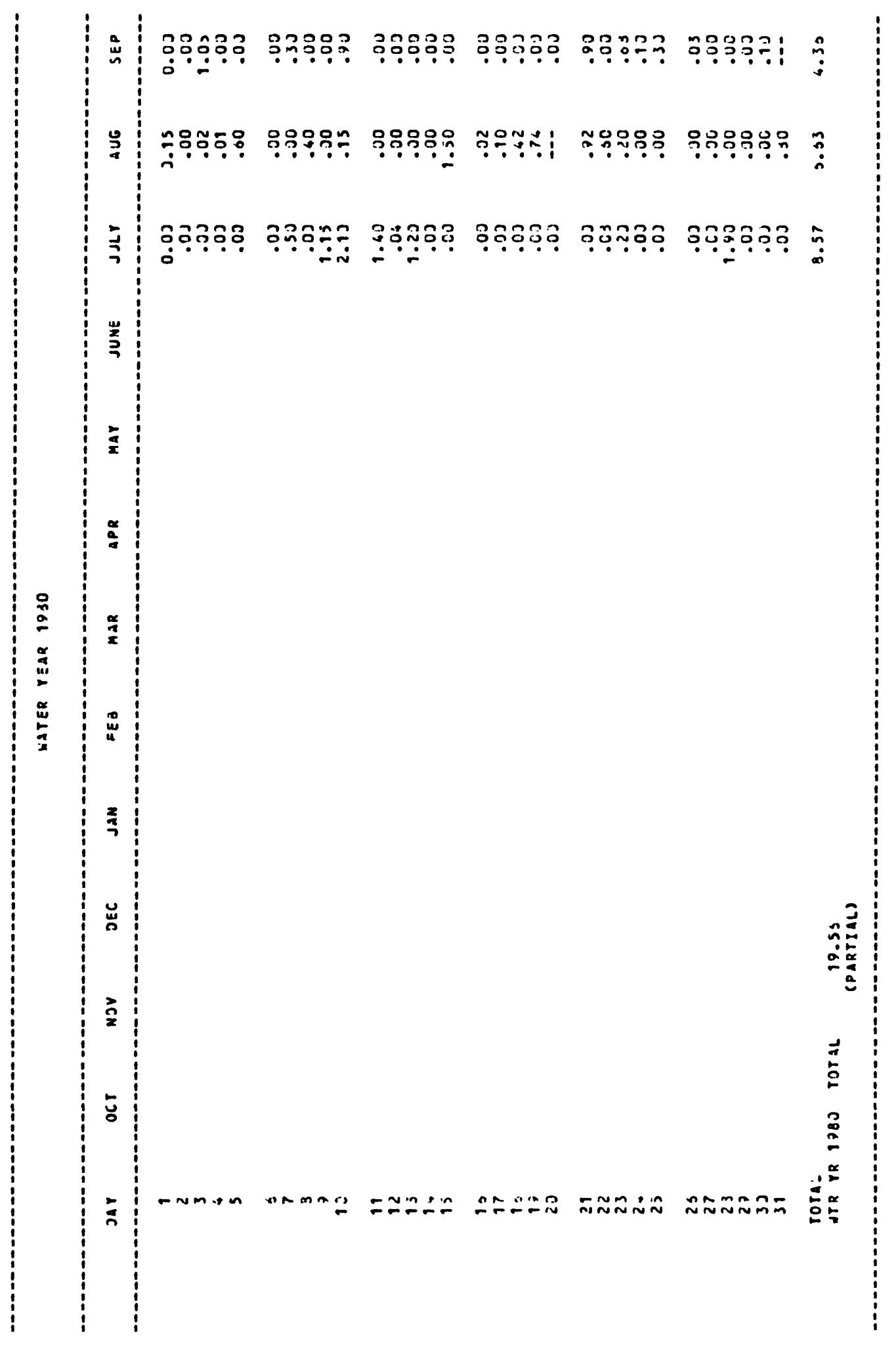




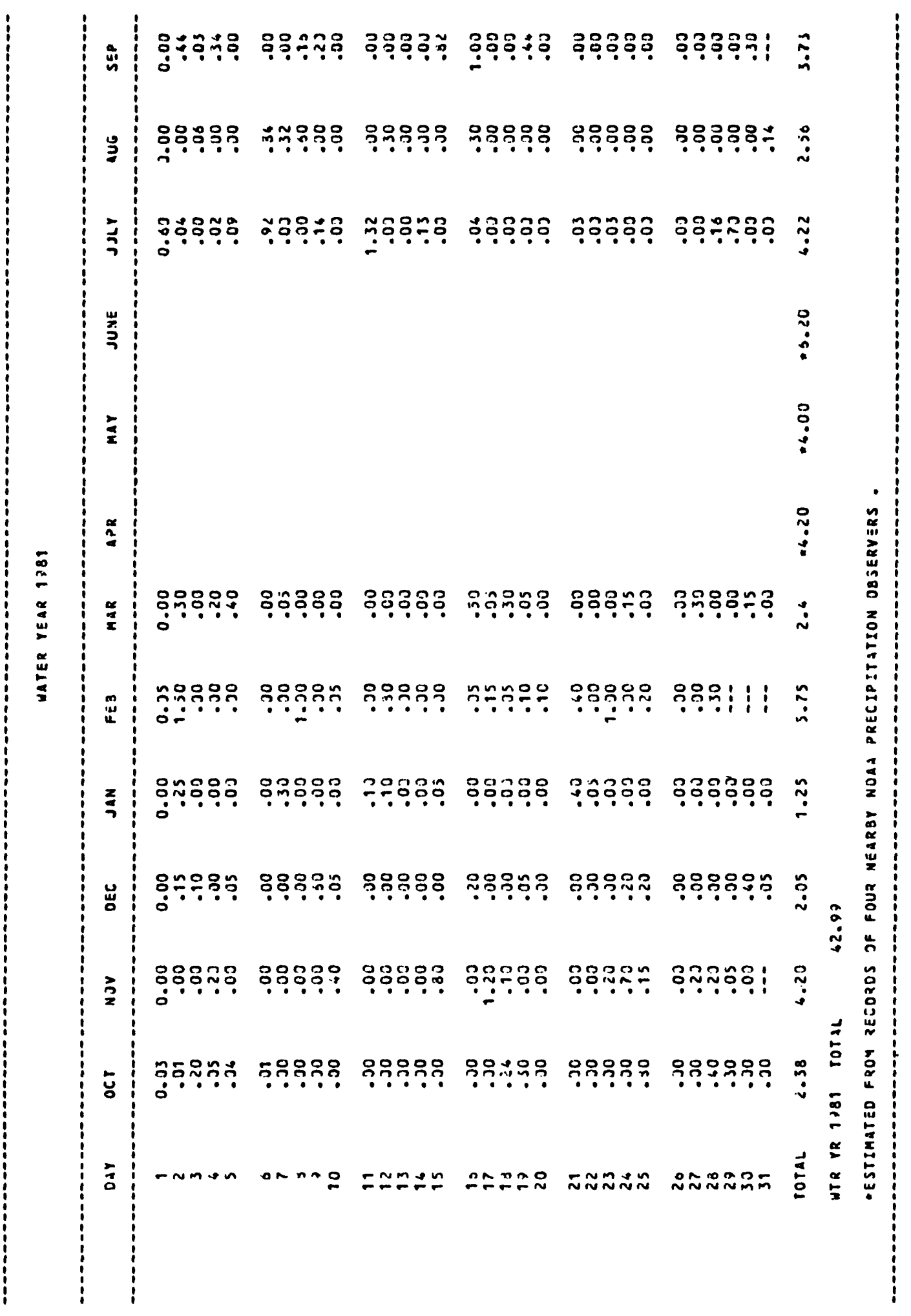




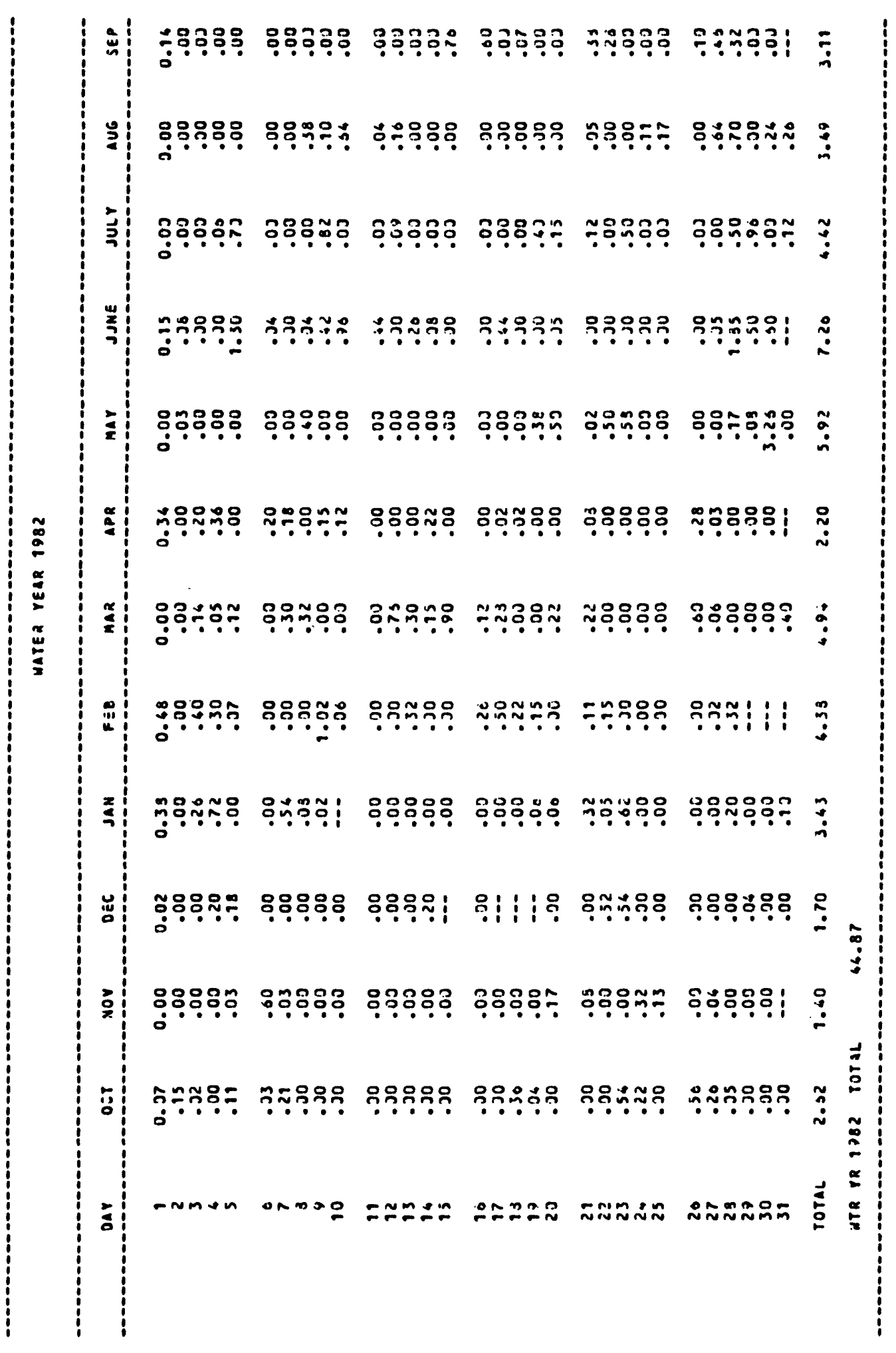




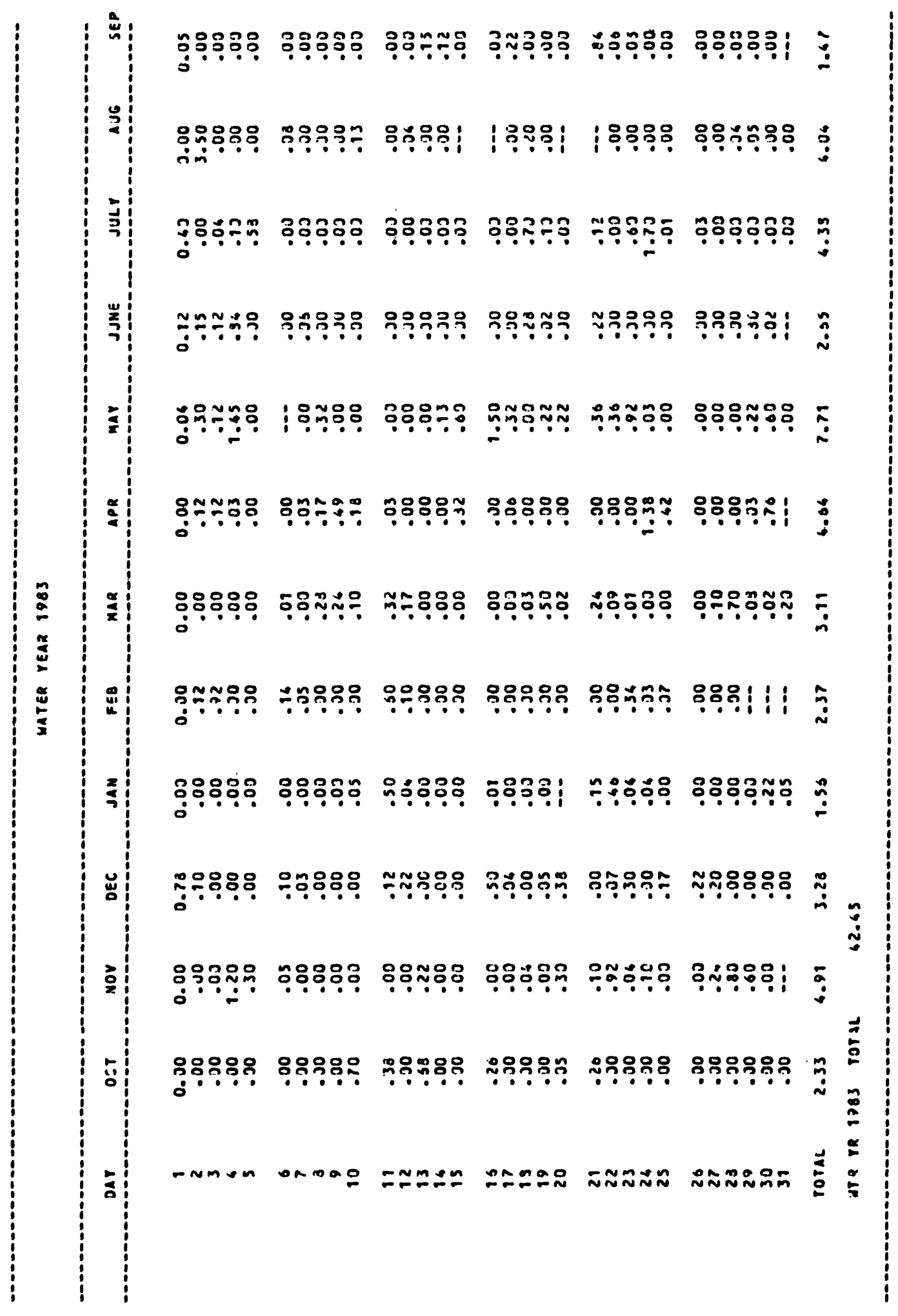




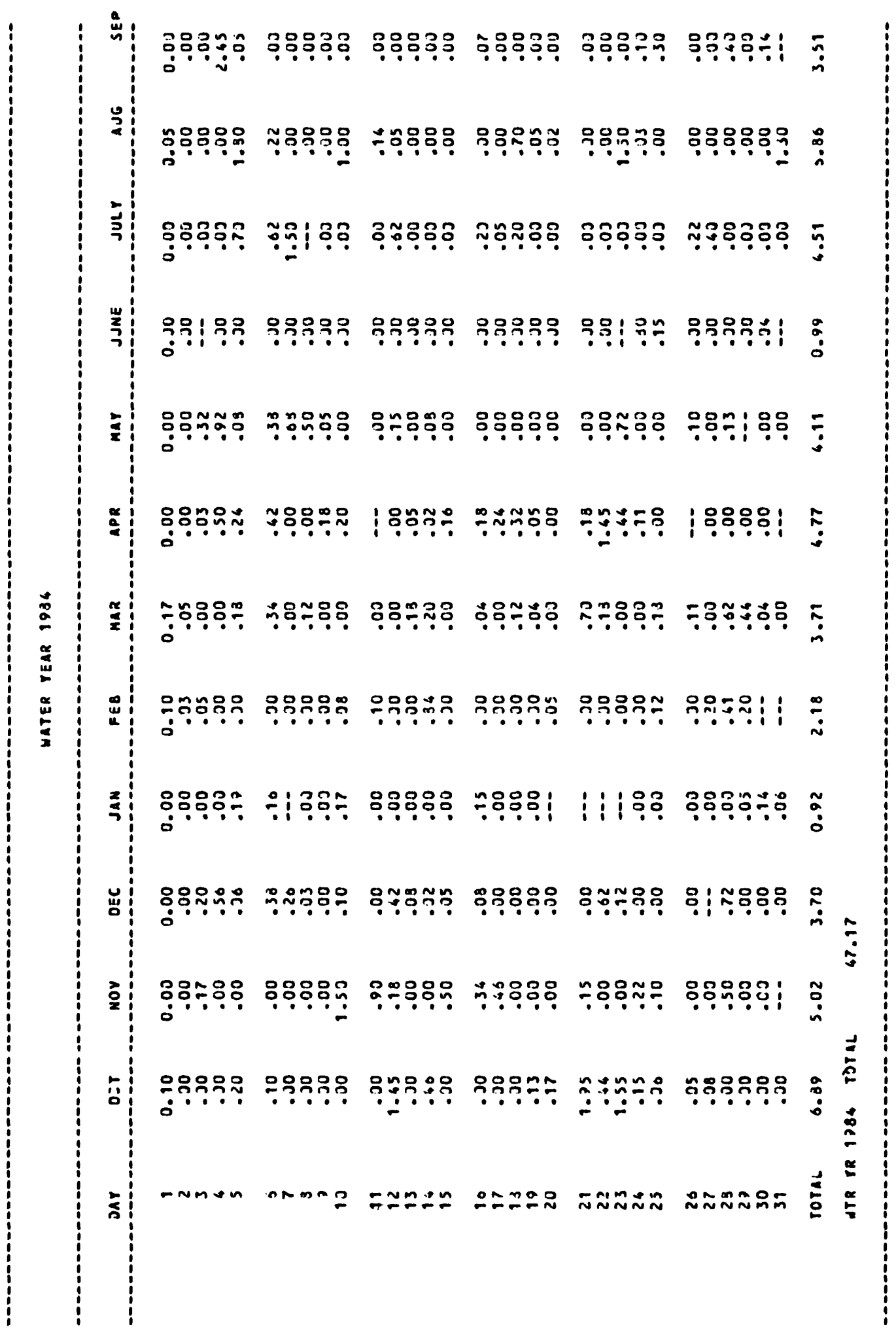

